\title{
An Empirical Study of Patent Litigation Timing: Could a Patent Term Reduction Decimate Trolls Without Harming Innovators?
}

Brian J. Love

Santa Clara University School of Law, blove@scu.edu

Follow this and additional works at: http://digitalcommons.law.scu.edu/facpubs

Part of the Law Commons

\section{Automated Citation}

Brian J. Love, An Empirical Study of Patent Litigation Timing: Could a Patent Term Reduction Decimate Trolls Without Harming Innovators? (2011),

Available at: http://digitalcommons.law.scu.edu/facpubs/542 


\title{
AN EMPIRICAL STUDY OF PATENT LITIGATION TIMING: COULD A PATENT TERM REDUCTION DECIMATE TROLLS WITHOUT HARMING INNOVATORS?
}

\author{
Brian J. Love* \\ Preliminary draft
}

This article reports the findings of an empirical analysis of the relative ages of patents litigated by practicing and non-practicing patentees. Studying all infringement claims brought to enforce a sample of recently expired patents, I find considerable variance. Product-producing companies predominately enforce their patents soon after issuance and complete their enforcement activities well before their patent rights expire. NPEs, by contrast, begin asserting their patents relatively late in the patent term and frequently continue to litigate to the verge of expiration. This variance in litigation timing is so dramatic that all claims asserting the average product-company patent are resolved before the average NPE patent is asserted for the first time. Further, I find that NPEs are the dominate source of patent enforcement in the final few years of the patent term. NPEs, enforcers of just twenty percent of all studied patents, are responsible for more than two-thirds of all suits and over eighty percent of all patent claims litigated in the final three years of the patent term. These findings cast serious doubt on the utility of the last few years of the patent term and suggest that Congress should, at a minimum, act to increase the frequency and magnitude of maintenance fee payments in the latter half of the patent term.

* (c) 2011 Brian J. Love. Lecturer in Law, and Teaching Fellow in Law, Science and Technology, Stanford Law School. Thanks to Mark Lemley, Colleen Chien, and Michael Risch for comments on an earlier draft, and to participants at the 2011 IP Scholars Conference and the Stanford Law School Fellows Workshop. Thanks also to Gabriel Dobbs for research assistance and to the Stanford Program in the Law and Economics of Intellectual Property and Antitrust for generous support. Comments welcome: blove@law.stanford.edu. 


\section{INTRODUCTION}

The study of non-practicing entities ("NPEs"), or "patent trolls" to some, is among the most important of all patent-related empirical endeavors. So far, however, scholars have analyzed litigation brought by various types of patent owners in a rather fragmented and indirect fashion. Some have studied only the most litigious or easily identifiable "trolls."1 Such studies miss as much as ninety percent of NPE-asserted patents. ${ }^{2}$ Others have focused exclusively on litigation filed during a handful of years in the last decade. ${ }^{3}$ These studies fail to account for vast differences among patents that happen to be litigated at the same time. It makes little sense, for example, to compare the first-and-only litigation of a one-year-old medical device patent to the twentieth litigation of a nineteen-year-old software patent, even if both proceed contemporaneously.

Perhaps not surprisingly, these narrow studies have produced results at odds with one another. The empirical literature examining NPEs is, to put it mildly, internally inconsistent. Some studies strongly suggest that NPEs are every bit the tail that wags the dog. NPEs, for example, assert the lionshare of most-litigated patents ${ }^{4}$ and are especially dominate in high-tech fields, where patents tend to be plentiful, cheap, and broad. ${ }^{5}$ Others report the

${ }^{1}$ See Michael Risch, Patent Troll Myths, 42 Seton Hall L. Rev. (forthcoming 2012) (studying only "the ten most litigious NPEs"); John R. Allison, et al., Patent Quality and Settlement Among Repeat Patent Litigants, 99 GEO. L.J. 677 (2011) [hereinafter Patent Quality and Settlement] (comparing the characteristics, including NPE-status, of patents asserted eight or more times and patents asserted just once); John R. Allison, et al., Extreme Value or Trolls on Top? The Characteristics of the Most-Litigated Patents, $158 \mathrm{U}$. PA. L. REV. 1 (2009) [hereinafter Extreme Value] (studying the same "most-litigated" patents); see also Sannu K. Shrestha, Trolls or Market Makers? An Empirical Analysis of Non-Practicing Entities, 110 COLUM. L. REV. 114, 147-48 (studying only those NPEs identified in the press as NPEs).

${ }^{2}$ In the sample gathered for this study, less than ten percent of NPE-asserted patents (eight of eighty-four) were litigated in eight or more suits. About seven percent (six of eighty-four) were asserted by the ten NPEs studied by Michael Risch.

${ }^{3}$ See Patent Quality and Settlement, supra (studying litigation brought between 2000 and 2007); Extreme Value, supra (studying the same cases); Colleen V. Chien, Of Trolls, Davids, Goliaths, and Kings: Narratives and Evidence in the Litigation of High-Tech Patents, 87 N.C. L. REV. 1571 (2009) (studying high tech cases filed between January 2000 and March 2008); Gwendolyn G. Ball \& Jay P. Kesan, Transaction Costs and Trolls: Strategic Behavior by Individual Inventors, Small Firms and Entrepreneurs in Patent Litigation (working paper 2009) (studying every case filed between 2000 and 2002).

${ }^{4}$ Patent Quality and Settlement, supra note _ at *15 (reporting that NPEs filed 63.5 percent of patent cases asserting patents litigated eight or more times, but just 21 percent of cases asserting patents litigated only once).

${ }^{5}$ Id. at $* 18$ (further reporting that over seventy-four percent of the most-litigated patents cover software-related inventions); Chien, Of Trolls, supra note _ at 1572 (reporting that a subset of NPEs account for seventeen percent of patent suits and twenty- 
exact opposite. Trolls really don't exist at all, ${ }^{6}$ exist but are exceedingly rare, ${ }^{7}$ or exist in modest numbers but hold few of the traits attributed to them by their detractors. ${ }^{8}$

This article fills the aforementioned gaps in the existing literature by studying a broad cross-section of patents over the entire patent term. Rather than a subset of patents linked by litigiousness or contemporaneous court filings, I study a random sample of all recently expired patents and collect data on all patent enforcement undertaken prior to their expiration.

With data on all litigation filed during these patents' lives, I can for the first time report results taking into account the relative timing of litigation filed by practicing and non-practicing entities. My findings are dramatic. Opposing views of NPEs in the literature ring true, but at opposite ends of the patent term. Product companies predominately enforce their patents soon after they issue and complete their enforcement activities well before their patents expire. NPEs, on the other hand, begin asserting their patents relatively late in the patent term and frequently continue to litigate their patents to the verge of expiration. Indeed, I find that the average productcompany patent has been shelved by its owner before the average NPE patent has even been asserted.

The degree to which NPEs dominate the final few years of the patent term is especially shocking. Though asserting just over twenty percent of all studied patents, NPEs account for more than two-thirds of suits and over eighty percent of patent claims litigated in the final three years of the patent term. Notably, NPEs' domination of late-term litigation is almost completely attributable to firms that do nothing more than hold patents. NPEs that many do not consider trolls - universities and individual inventors, in particular - do not drive the results reported below. ${ }^{9}$

eight percent of patent claims in high-tech industries); Mark A. Lemley \& Carl Shapiro, Patent Holdup and Royalty Stacking, 85 TEX. L. REV. 1991, 2009 (2007) (estimating that NPEs file thirty to forty percent of patent suits involving computer and electronic technology).

6 See Innovators Fear the Patent Trolls, TMCNEws, May 7, 2006, http://www.tmcnet.com/usubmit/2006/05/07/1639931.htm ("Patent trolls 'don't exist. Trolls are imaginary creatures . . . . I think the whole issue is overblown." (quoting Carl Gulbrandsen, Managing Director of the Wisconsin Alumni Research Foundation)); Michael C. Smith, "Patent Pirates” Only Exist in Neverland, TEX. LAWYER, Oct. 11, 2004.

${ }^{7}$ Ball \& Kesan, supra note _, at 2 ("We find that licensing firms . . . are a very small percentage of all plaintiffs .... [and] our results suggest that patent litigation is not dominated by 'trolls' .....”); Marc Morgan, Stop Looking Under the Bridge for Imaginary Creatures: A Comments Examining Who Really Deserves the Title Patent Troll, 17 FED. CIR. B.J. 165, 166 (2007) (estimating that "only two percent of all patent litigation is linked to so-called trolling").

${ }^{8}$ Risch, supra note _; Shrestha, supra note _.

${ }^{9}$ See Mark A. Lemley, Are Universities Patent Trolls?, 18 FordHAM InTELL. PROP. 
I also compare the relative litigiousness of product companies and NPEs, as well as differences in the subject matter and strength of their infringement claims. In addition to overall findings, I report how these statistics change among patents litigated in the final years of the patent term. I find that NPEs are especially litigious, overwhelmingly assert hightech patents, and lose at a relatively high rate when their infringement claims are adjudicated on the merits. I also find that, with patents litigated late the patent term, NPEs are more litigious, more high-tech focused, and more likely to lose on the merits of their infringement claims. Interestingly, I also find that an outsized percentage of product company patents litigated late in the term are high-tech related. These patents, I find, are asserted by a unique group of companies that, though they sell a product, blur the line between practicing entities and trolls.

My findings add to mounting evidence that the costs of NPE litigation outweigh their benefits. In fact, they cast serious doubt on NPEs' chief alleged benefits: that paper patentees help create a market for innovation and contribute to the dissemination of useful technology. Instead, it seems, NPEs overwhelmingly wait to assert their rights until the underlying technology is stale and unlikely to be of much use to accused infringers, who very likely independently developed the technology years earlier. ${ }^{10}$ Overall, my findings suggest that Congress may be well-advised to shorten the patent term by three years or even longer. ${ }^{11}$ In these final years of patent protection, more than eighty percent of patent assertions are brought by patent-holding firms that have no intention of commercializing a product. Much of the remaining litigation is brought by product companies asserting high-tech patents with far less than ideal motivation. At the very least, Congress and the PTO should act to increase the frequency and magnitude of maintenance fee payments required in the latter half of the patent term.

MEDIA \& ENT. L.J. 611 (2008) (arguing that universities are not "trolls"); Chien, Of Trolls, supra note _, at 1578 (arguing that individual inventors also fall outside the scope of patentees that deserve the label "troll").

${ }^{10}$ See Christopher A. Cotropia \& Mark A. Lemley, Copying in Patent Law, 87 N.C. L. REV. 1421, 1424 (2009) (finding that allegations of copying are rare in patent litigation, especially in cases asserting high-tech patents).

${ }^{11}$ For a discussion of study limitations that temper this recommendation, including a discussion of NPEs' ability to simply file suit earlier in the event of a term reduction, see infra Part III.C. 


\section{STUDy DESIGN}

On the issue of patent reform, a civil war of sorts divides the technology community. ${ }^{12}$ In this fight, battle lines are drawn largely between industries. Pharmaceutical companies, on one side, argue that strong patent rights are crucial to continued innovation. High-tech firms, on the other, view the patent system more as foe than friend. According to these firms, and echoed by many scholars and patent attorneys, the patent system is far too often a vehicle for "patent trolls" - entities that assert patents they do not use and frequently did not invent - to extract undeserved royalties from true innovators working to build successful new high-tech products. ${ }^{13}$

How these opposing views of the patent system should be reconciled turns in large part on questions concerning the utility of NPEs. Are NPEs the pervasive litigation cost extortionists their detractors make them out to be $?^{14}$ Or are they, as their defenders contend, small-time players that help disseminate useful technology ${ }^{15}$ and create markets for inventions ${ }^{16}$ and safety nets for inventors? ${ }^{17}$

\section{A. Hypotheses}

Unfortunately, existing literature has done little to settle the debate. One reason is that, even after several studies on the topic, commentators

${ }^{12}$ See,e.g., Dan L. Burk \& Mark A. Lemley, The Patent Crisis and How the COURTS CAN SOLVE IT 3-6 (2009).

${ }^{13}$ Patent "trolls" are so named because they bear resemblance to mythological trolls who emerge without warning from beneath bridges to demand a toll from all who pass.

${ }^{14}$ See, e.g., Timothy J. Haller \& Sally Wiggins, The Patent Troll Myth, in IP VALUE 2006, at 113 (2006) (explaining that in 1991 Intel was sued for libel after referring to an NPE as a "patent extortionist"); Ted Sichelman, Commercializing Patents, 62 STAN. L. REv. 341, 368 (2010); Gerard N. Magliocca, Blackberries and Barnyards: Patent Trolls and the Perils of Innovation, 82 NotRe DAME L. REV. 1809, 1830 (2007).

${ }^{15}$ See John C. Paul, et al., Patent Trolls: A Stereotype Causes a Backlash Against Patents and Licensing, 41 LES NouvelLes 224, 232 (2006).

${ }^{16}$ See James F. McDonough III, Comment, The Myth of the Patent Troll: An Alternative View of the Function of Patent Dealers in an Idea Economy, 56 EMORY L.J. 189, 190 (2006) ("[P]atent trolls make the patent market more efficient by realigning market participant incentives, making patents more liquid, and clearing the patent market.").

${ }^{17}$ See John E. Dubiansky, An Analysis for the Valuation of Venture Capital-Funded Startup Firm Patents, 12 B.U. J. SCI. \& TECH. L. 170, 171-72 (2006); Ronald J. Mann, Do Patents Facilitate Financing in the Software Industry?, 83 TEX. L. REV. 961, 1024 (2005) ("[T]rolls are serving a function as intermediaries that specialize in litigation to exploit the value of patents that cannot be exploited effectively by those that have originally obtained them."). 
cannot agree what percentage of patent enforcement is attributable to NPEs. Results have been all over the map. NPEs, or some "trollish" subset thereof, account for two, ${ }^{18}$ four, ${ }^{19}$ eighteen, ${ }^{20}$ or twenty-seven ${ }^{21}$ percent of patent litigation depending on whom you ask. Though diverse, these relatively modest estimates have led at least one scholar to declare that "the uniform findings indicate that NPEs file only a small fraction of all patent infringement suits." ${ }^{22}$ Other tantalizing clues, however, suggest that NPEs have anything but a modest effect on the patent system. A study of patents litigated eight or more times, for example, found that NPEs owned more than sixty percent, ${ }^{23}$ and multiple studies have found that NPEs file as much as forty percent of suits asserting high-tech patents. ${ }^{24}$

What accounts for these seemingly inconsistent results? This article tests the hypothesis that existing studies of NPE litigation are incomplete because they fail to take into account differences in the relative ages of patents asserted by practicing and non-practicing entities. In fact, it suggests that all previous empirical studies underestimate NPEs' true impact because they fail to compare NPE patents with other patents their own age.

To date, no scholar studying NPEs' share of patent litigation has included a temporal component in her analysis. ${ }^{25}$ This omission is surprising because there is good reason to believe that product-producing companies and NPEs assert their patents on very different timelines. If, as many suggest, patentees who sell products covered by their patent rights primarily value patents for their exclusionary power, ${ }^{26}$ these patentees

18 Morgan, supra note _, at 166 (estimating that "only two percent of all patent litigation is linked to so-calle- trolling"); Nathan Myhrvold, Inventors Have Rights, Too!, WALL ST. J., Mar. 30, 2006, at A14 (reporting the same statistic).

${ }^{19}$ Ball \& Kesan, supra note _, at 15 (finding that " $3 \%$ of plaintiffs, who were active in $4 \%$ of the cases, were licensing firms").

${ }^{20}$ Compare LexMachina, Fora, https://lexmachina.com/members/ courts?filter=Patent (reporting that there were 2572 patent cases filed in U.S. district courts in 2008, 2586 in 2009, and 2835 in 2010) with Patent Freedom, Current Research: Litigations Over Time, https://www.patentfreedom.com/research-lot.html (showing that there were just over 500 NPE-filed suits in 2008, just under 500 in 2009, and about 425 in 2010).

${ }^{21}$ Colleen V. Chien, Predicting Patent Litigation, at *31-32 (working paper 2011) (finding in a sample of 667 litigated patents issued in 1990 that 27\% were asserted by either a "patent assertion entity" or an individual).

${ }^{22}$ Risch, supra note _, at 8.

${ }^{23}$ Patent Quality and Settlement, supra note _ at *15 (reporting that NPEs filed 63.5 percent of patent cases asserting patents litigated eight or more times).

${ }^{24}$ Chien, Of Trolls, supra note _, at 1572; Lemley \& Shapiro, supra note _, at 2009.

${ }^{25}$ Michael Risch found that highly-litigious NPEs asserted their patents on average longer than 8.5 years after issue, but did not compare this delay with data on product companies' timing. Risch, supra note _, at 27-28.

${ }^{26}$ See Daniel A. Crane, Intellectual Liability, 88 TEX. L. REV. 253, 286 (2009) (noting 
should file suit (if at all) soon after their patents issue to fend off competitors developing or introducing similar products. In addition, because products generally have short lifecycles relative to the patent term ${ }^{27}$ and next generation products may be protected by newer patents, practicing patentees should generally cease litigating a patent well before it expires and move on to litigating newer patents covering newer products.

By contrast, there is good reason to believe that NPEs overwhelmingly litigate their patents late in the patent term. For one, many NPEs do not file their own patent applications, but instead purchase patents on the secondary market (often from failed companies ${ }^{28}$ ) for the purposes of litigation. ${ }^{29}$ Naturally, it takes time for such patents to reach NPEs. ${ }^{30}$ Further because NPEs primarily value patents for their usefulness in extracting royalties and damages from product-producing companies, ${ }^{31}$ these patentees should generally wait to file suit until a lucrative industry has developed and continue filing suits as long as deep-pocketed targets remain. ${ }^{32}$

If these characterizations are rooted in fact rather than anecdote, it makes little sense to base patent policy on calculations of the bare percentage of NPE suits among those brought during some year or group of years. Product companies are far and away the chief players in the patent system and such studies will always reflect this fact. ${ }^{33}$ What they cannot reflect, however, is whether NPEs begin to have a disproportionate effect at some point during the patent term and how such a finding would color NPEs' claims that they are beneficial market makers and disseminators of technology.

that NPEs and product companies "have asymmetrical incentives, since trolls are only interested in exacting payments whereas commercializers often resolve infringement disputes with other commercializers through cross-licensing arrangements").

${ }^{27}$ In the computer industry, for example, products become twice as powerful about every two years. See infra note _.

${ }^{28}$ Risch, supra note _, at $2 \overline{7}$ (finding that over one quarter of companies from which studied NPE patents were acquired were no longer operating).

${ }^{29}$ See, e.g., Crane, supra note _, at 286 ("Patent trolls are firms that aggregate patents for technology that they usually did not themselves create and do not themselves use, but for which they seek to exact royalty payments from commercial users.").

${ }^{30}$ See infra, Part _.

${ }^{31}$ See supra note _.

${ }^{32}$ See Mann, supra note _, at 1027 (noting "a particular type of conduct by trolls that is viewed as especially damaging by industry executives: the strategy of waiting after a patent has been issued while an industry advances using the covered technology and then suing widely for infringement only after the industry has become locked into the technology through independent innovation and development").

${ }^{33}$ See Figure 1 infra. 


\section{B. Compiling a Database}

To test these hypotheses, I set out to collect data on all litigation asserting a sample of recently expired patents. Using Westlaw and PACER, ${ }^{34}$ I located every litigated ${ }^{35}$ patent $^{36}$ that issued with a patent number falling between 5,210,000 and 5,309,999. These patents issued between May 11, 1993 and May 10, 1994 ("the study period"). ${ }^{37}$

As shown below in Table 2, I identified 1,143 patents issued during the study period ${ }^{38}$ that were litigated in a district court, the Court of Federal

34 Public Access to Court Electronic Records, http://www.pacer.gov/psco/cgibin/links.pl.

${ }^{35}$ Here and throughout, by "litigated" I mean asserted in an action raising a claim for infringement (or for a declaration of noninfringement or invalidity of) the studied patent, as opposed to merely involved in litigation concerning ownership, inventorship, antitrust, contract, trademark, copyright, or other patent claims. See infra Part _.

${ }^{36}$ Here and throughout, I use "patent" to refer exclusively to "utility" patents. This study does not include design patents or plant patents, both of which are protected by separate statutory schemes. See 35 U.S.C. $§ \$ 171-73$ (design patents); 35 U.S.C. §§ 16164 (codifying the Plant Protection Act); 7 U.S.C. $\S \S 2321-2582$ (codifying the Plant Variety Protection Act).

${ }^{37}$ Under the law in effect at the time these patents issued, each would have expired between May 11, 2010 and May 10, 2011. 35 U.S.C. § 154 (1988) (setting the patent term at seventeen years from the date the patent issued). Legislation passed in December 1994 modifying the patent duration granted patents then-in-force the longer of 17 years from issue or 20 years from filing. 35 U.S.C. $§ 154(c)(1)$. Because an application spends on average close to three years at the PTO, these calculations generally provide a similar term of protection. See John R. Allison \& Mark A. Lemley, The Growing Complexity of the United States Patent System, 82 B.U. L. ReV. 77, 98 (2002) (finding that patents issued between 1996 and 1998 spent an average of 2.77 years in prosecution). Many patents, however, receive a modest extension under the new law. See Mark A. Lemley, An Empirical Study of the Twenty-Year Patent Term, 22 AIPLA Q.J. 369, 385 (1994) (finding that, on average, the twenty-year calculation extended patentees' rights by 253 days in the mid-1990s).

Thus, while the vast majority of these patents expired in 2010 or early 2011, a minority remain in force. Because suits are very rare in the waning months of the patent term, however, this fact should not significantly impact the results reported below. Less than $0.75 \%$ of suits asserting now-expired patents were brought in the last year of the patent term; less than $0.25 \%$ were filed in the last four months. No patent issued during the study period has been asserted for the very first time since March 2011. Today, patent pendency times are much longer than they were in the late 1980s and early 1990s. At the close of 2009, the PTO employed just over 6,000 examiners and faced a backlog of more than 700,000 applications awaiting their first office action. U.S. Patent \& Trademark Office, Patent Inventory Statistics--FY09 (2009), http://www.uspto.gov/patents/stats/appbacklog.jsp.

${ }^{38}$ The earliest, U.S. Patent No. 5,210,272, issued on May 11, 1993; the latest, U.S. Patent No. 5,309,861, on May 10, 1994. This rate of assertion (1.143\%) comports with prior estimates of the percentage of litigated patents. See Chien, Predicting Patent Litigation, supra note _, at $* 9, \mathrm{n} .37$ (estimating that approximately $0.6 \%$ to $1.1 \%$ of issued 
Claims, or at the International Trade Commission ("ITC"). ${ }^{39}$ In the 90 district courts located in U.S. states and the District of Columbia, court clerks' offices report basic information on patent suits to the PTO, and searchable copies of these reports are available via Westlaw's Derwent LitAlert database. ${ }^{40}$ From these reports I identified 1,124 patents. $^{41}$ The LitAlert database, however, does not include records for cases filed in the remaining four "territorial" district courts. ${ }^{42}$ To locate all identifiable patents asserted solely in these courts, I searched PACER docket reports and pleadings (where available ${ }^{43}$ ) for all patent cases brought in each court

patents are litigated); Mark A. Lemley, Rational Ignorance at the Patent Office, $95 \mathrm{Nw}$. U. L. REV. 1495, 1507 (2001) (estimating that only about $1.5 \%$ of patents are ever litigated).

${ }^{39}$ Patent suits fall within the exclusive subject matter jurisdiction of federal courts, 28 U.S.C. § 1338(a), and may generally be brought in any U.S. district court which has personal jurisdiction over the defendant, see generally Int'l Shoe Co. v. Washington, 326 U.S. 310 (1945), and where venue is proper, 28 U.S.C. $§ 1400(b)$. One exception is patent claims against the United States, which must be brought in the Court of Federal Claims. 28 U.S.C. $\S 1498$. The ITC holds in rem jurisdiction over imported goods that infringe a U.S. patent. 19 U.S.C. $\S 1337(a)(1)(B)(i)$. ITC orders barring the entry of infringing goods into the U.S. may be appealed to the Court of International Trade. 19 U.S.C. § 1514(a)(4). The Court of Appeals for the Federal Circuit holds appellate jurisdiction over the Court of Federal Claims, the Court of International Trade, and all patent-related cases brought in district courts. 28 U.S.C. § 1295(a)(1),(3),(5). See also David L. Schwartz, Pre-Markman Reversal Rates, 43 LOY. L.A. L. REV. 1073, 1077 (2010) (noting that patent litigation occurs "in the federal district courts, the International Trade Commission, and the Court of Federal Claims").

${ }^{40}$ Searching the LitAlert database confirms that all 90 districts located in the 50 states (and D.C.) submitted litigation reports to the PTO throughout the 1990s and 2000s. Thus, any missing patents should be attributable to idiosyncratic oversight, rather than widespread failure in any particular district to file reports with the PTO.

${ }^{41}$ Patents from this timeframe were asserted in 74 of the 90 total districts, including districts located in 45 of the 50 states and the District of D.C. Each of the top 46 districts, ranked by number of patent filings since 2000, is represented. See LexMachina, Fora, https://lexmachina.com/members/courts?filter=Patent. These 74 districts account for over $98 \%$ of patent suits filed since 2000. See id.

${ }^{42}$ These four are the District of Guam, District for the Northern Mariana Islands, District of Puerto Rico, and District for the Virgin Islands. This is not surprising because these four "territorial" districts collectively see about one patent case per year. See id. (reporting that between 2000 and 2010 just 14 patent suits were filed in these four territories). Virtually all of these cases were filed in the District of Puerto Rico, which apparently ceased sending patent litigation reports to the PTO in the 1980s.

${ }^{43}$ Starting in approximately 2000 and continuing incrementally thereafter on a district by district basis, federal court filings and orders are available online in pdf format. Prior to electronic filing, docket entries are simply described in short on docket reports. Thus, despite hand collection, this data set is potentially under-inclusive for "territorial" district courts and the Court of Federal Claims. Nonetheless, collection in this manner gives "the best, most representative data set available." Patent Quality \& Settlement, supra note _, at 5 , n.22 (discussing limitations in data collected from PACER by the Stanford IP Litigation Clearinghouse). 
during or after 1993 and cross-referenced these results with all relevant patent numbers cited in opinions or orders issued by any of these courts in 1993 or later. From these records I was able to locate another two unique patent numbers, and two duplicates. ${ }^{44}$ Similarly, to locate all identifiable patents asserted solely against the U.S., I searched PACER docket reports and pleadings for all patent cases brought in the Court of Federal Claims during or after 1993 and cross-referenced these results with all relevant patent numbers cited in opinions or orders issued by the court in 1993 or later. From these records I was able to locate another five unique patent numbers, and one duplicate. ${ }^{45}$ Finally, to locate all identifiable patents asserted only at the ITC, ${ }^{46}$ I searched Westlaw's database of ITC filings and cross-referenced these results with all relevant patent numbers cited in opinions or orders issued by the U.S. Court of International Trade in 1993 or later. ${ }^{47}$ From these records, I was able to locate another twelve unique patent numbers, and twenty-two duplicates.

\section{Table 1: Database Composition by Venue}

\begin{tabular}{|c|c|c|c|}
\hline Patents: & Total & Unique & Source: Database \\
\hline U.S. District Courts & 1,124 & - & Westlaw: LITALERT \\
\hline U.S. Territorial Courts & 4 & 2 & $\begin{array}{l}\text { PACER; Westlaw: DCTGU, } \\
\text { DCTMP, DCTPR, DCTVI }\end{array}$ \\
\hline Court of Federal Claims & 6 & 5 & PACER; Westlaw: FEDCL \\
\hline ITC/Court of Int'1 Trade & 34 & 12 & $\begin{array}{l}\text { Westlaw: USITC-FILINGS, } \\
\text { FINT-CIT }\end{array}$ \\
\hline
\end{tabular}

\section{Sampling and Data Collection}

From these 1,143 patents, I randomly selected a sample of 450 to

\footnotetext{
${ }^{44}$ I identified a total of four patents issued during the study period that were asserted in a "territorial" district court, but two were also asserted in a district court.

${ }^{45}$ These were the only five. No patents issued during the study period were asserted in a district court and in the Court of Federal Claims.

46 Technically, the ITC's jurisdiction is in rem, so the suit is brought against the allegedly infringing goods themselves. See Sealed Air Corp. v. U.S. Int'l Trade Comm'n, 645 F.2d 976, 985-86 (C.C.P.A. 1981).

${ }^{47}$ Westlaw's coverage of ITC filings dates back to December 1994. See Westlaw, Scope USITC-FILINGS, https://web2.westlaw.com/scope/ default.aspx?db=USITC\%2DFILINGS\&RP=/scope/default.wl\&RS=WLW11.07\&VR=2.0 $\& S V=S p l i t \& F N=$ top $\& M T=W e s t l a w \& M S T=$. Thus, this data set is underinclusive to the extent that patents issued during the study period were asserted at the ITC within about a year of issue.
} 
investigate in depth. Forty-one patents in this sample were excluded because they were never asserted against an alleged patent infringer. Of these forty-one, thirteen patents were solely involved in litigation brought to resolve a dispute between putative owners or inventors. Nine more were involved in patent "false marking" cases brought after their expiration. ${ }^{48}$ Another thirteen were not litigated, but merely cited in pleadings. ${ }^{49}$ Five additional patent numbers were excluded because they contained a typographical error, ${ }^{50}$ and one final patent was erroneously asserted long after it had expired for failure to pay maintenance fees.

For each of the remaining 409 patents, I collected a variety of data that would allow me to determine when during its term of protection, in how many suits, and against how many infringers the patent was enforced. Also, in order to compare the relative ages of patents asserted by practicing and non-practicing entities, I categorized the party enforcing each patent using patentee classes developed by Lemley and Myhrvold. ${ }^{51}$ Finally, in order to compare the diversity of technology enforced by practicing and nonpracticing entities, I categorized the invention claimed in each patent using technology and industry classes developed by Allison, Lemley, and Walker. ${ }^{52}$

4835 U.S.C. $§ 292$ makes it unlawful to mark a product with an expired patent number and empowers the public to bring qui tam suits against alleged false markers seeking statutory damages of "not more than $\$ 500$ for every such offense." In 2009, the Federal Circuit held that this language authorized awards of up to $\$ 500$ per article, rather than per decision to mark. Forest Group, Inc. v. Bon Tool Co., 590 F.3d 1295, 1304 (Fed. Cir. 2009) (reversing a $\$ 500$ award and remanding for determination of "the number of articles falsely marked ... [and] the amount of penalty to be assessed per article"). A flood of litigation soon followed. See R. Mark McCareins \& Peter Slawniak, Current State of Patent False Marking Litigation, 23 InTELl. ProP. \& TECH. L.J. 3, 3 (2011) (noting that more than 600 false marking suits were filed in 2010). Pending patent reform legislation passed in both Houses would amend section 292 to retroactively strip jurisdiction from most pending cases. See H.R. 1249, § 16; S. 23, § 2(k) (requiring false marking plaintiffs to show "competitive injury" and applying this change "to all cases, without exception, pending on or after the date of the enactment of this Act").

${ }^{49}$ Four were cited as prior art in an answer or declaratory judgment complaint. Nine were cited for another extraneous reason in pleadings bringing claims for trademark infringement, copyright infringement, unfair competition, and/or breach of contract.

${ }^{50}$ Westlaw's Derwent LitAlert database was rife with erroneously transcribed patent numbers. In the vast majority of cases, I was able to reverse engineer the correct patent number, but for a small minority I was unable to determine which patent was actually litigated. The vast majority of corrected patent numbers issued within the study period, but a small minority did not.

${ }^{51}$ Extreme Value, supra note _, at 10-11.

${ }^{52} I d$., at 6-8. I do not address my findings with respect to technology and industry in detail in this Article. These results are tentatively reserved for inclusion in a forthcoming companion piece. 


\section{Prosecution Data}

First, to calculate each patent's term, I determined the dates the patent was filed and issued. ${ }^{53}$ Specifically, I identified the U.S. filing date of each patent's application, or of the earliest U.S. parent application ${ }^{54}$ to which the patent claims priority. ${ }^{55}$ I also identified whether each patent's owner made all three maintenance fee payments and, if not, on which date the patent prematurely fell into the public domain. ${ }^{56}$

\section{Litigation Data}

Next, I identified enforcement statistics for each patent. ${ }^{57}$ Specifically, I identified:

(a) the date each patent was enforced for the first time: the filing date of the earliest complaint alleging infringement of the patent or seeking a declaration that the patent was not infringed or is invalid: ${ }^{58}$

(b) the date enforcement of each patent ceased: the date on which the very last claim asserting infringement of the patent, or seeking a contrary

${ }^{53}$ Both dates are found on the patent document itself.

${ }_{55}^{54}$ Prior foreign filing dates do not start the twenty-year term. 35 U.S.C. $§ 154(a)(3)$.

55 Many patent applications blossom over time into a "family" of divisional, continuation, and continuation-in-part child applications, each of which may in turn spawn their own children, and so on. See 35 U.S.C. $§ \S 120-21$; 37 C.F.R. 1.53(b), (d). It is frequently these subsequent applications, rather than their parents, which ultimately issue at patents. See Mark A. Lemley \& Kimberly A. Moore, Ending Abuse of Patent Continuations, 84 B.U. L. REV. 63, 70 (2004) (noting that over half of all litigated patents issue from continuation applications); Mark A. Lemley \& Bhaven Sampat, Is the Patent Office a Rubber Stamp?, 58 EMORY L.J. 181, 193 (2008) (finding that, taking continuation applications into account, the PTO grants patents to more than $70 \%$ of applicants).

${ }^{56}$ Failure to pay a maintenance fee within at least thirty months of the date on which it is assessed will result in the patent's expiration. 35 U.S.C. § 41(b)-(c).

${ }^{57}$ To locate the docket number of each case asserting a given patent, I cross-referenced results from three databases: (i) each case in which the patent was reported as asserted in Westlaw's Derwent LitAlert database, (ii) each additional case, if any, from which a document was listed on Westlaw's "citing references" for each studied patent, and (iii) each additional case, if any, returned by a search for the patent's number on the Stanford IP Litigation Clearinghouse. To exclude false positives and gather litigation statistics from true assertions, I relied on PACER docket reports for cases filed prior to 2000 and Stanford IP Litigation Clearinghouse docket reports for cases filed in 2000 or later. The dockets for three cases filed pre-2000 were, for unknown reasons, not available via PACER. See No. 97-CV-285 (D. Nev.); 96-CV-1040 (D. Nev.); 95-CV-782 (W.D. Tex.) Because I could not determine when these three cases were resolved, I excluded each patent from all analyses related to litigation end dates.

${ }^{58}$ Patents can, of course, be enforced without filing litigation. The fact is discussed in detail infra, in Part _. 
declaration, was resolved; ${ }^{59}$

(c) the total number of suits in which each patent was asserted: the total number of unique docketed cases in which the patentee asserted the studied patent or alleged infringers sought declaratory relief from an imminent assertion, excluding parallel case pairs and consolidated cases other than multi-district litigation; ${ }^{60}$

\footnotetext{
${ }^{59}$ In suits resolved by settlement (the vast majority of cases), I identified the date the court granted the parties' stipulated motion for dismissal or for a consent judgment. In suits resolved in the accused infringers' favor, I identified the date of the jury's verdict; the date on which the court granted the accused infringers' dispositive motion to dismiss (e.g., following a ruling that the patentee is not the true owner of the patent-in-suit), motion for summary judgment, or motion for judgment as a matter of law; or, in the event of an appeal, the date of the affirmance of any of the aforementioned. In suits resolved in the patentee's favor, I identified the date on which the court awarded damages and/or an injunction, or, in the event of an appeal, the date of affirmance of these remedies. Finally, for three suits in which an unsuccessful petition for certiorari to the Supreme Court was filed, I identified the date certiorari was denied.

I did not identify the date on which the case was "terminated" - i.e., the date on which the court administratively closed the case. Doing so would have counted days, months, or years spent litigating non-substantive post-trial or post-judgment issues, like motions for attorneys' fees and motions for sanctions. Also, in many cases, other claims (including claims for infringement of other patents) continued on after claims asserting the studied patent had been resolved. In these multi-claim cases, I identified the date specific to the claim for infringement (or DJ claim against) the studied patent.

60 Accused infringers will often file suit preemptively seeking a declaration of noninfringement or invalidity. The vast majority of these suits are filed close in time to a mirror-image patent infringement complaint brought by the patent owner. In fact, until recently, courts would only exercise jurisdiction over declaratory judgment actions showing that the plaintiff held "a reasonable apprehension of imminent suit." Teva Pharm. USA, Inc. v. Pfizer, Inc., 395 F.3d 1324, 1333 (2005), abrogated by MedImmune, Inc. v. Genentech, Inc., 549 U.S. 118 (2007). Patentees and accused infringers often race to the courthouse (albeit in different districts) in hopes of ultimately consolidating both suits in their forum of choice. See Kimberly A. Moore, Judges, Juries, and Patent Cases - An Empirical Peek Inside the Black Box, 99 Mich. L. Rev. 365, 404 (2000). As declaratory judgment plaintiffs, accused infringers may also hold a psychological advantage with juries. See id. at 368, 405 (finding that patentees win $68 \%$ of jury trials in patentee-filed infringement actions, but only $38 \%$ of trials held in accused infringer-filed declaratory judgment actions). These case pairs typically involve the same parties and proceed in parallel with one another. Because, for all intents and purposes, a declaratory judgment action brought in parallel with a patent infringement action is one suit, I counted them as such. In a similar fashion, ITC investigations often coincide with a patent infringement suit filed contemporaneously in district court. Again because, for all intents and purposes, an ITC investigation brought in parallel with a patent infringement action is one suit, I counted them as such.

Finally, I also merged data for individual suits that were so similar and contemporaneous that they were consolidated into a single action. The sole exception I made to this rule were multi-district litigations, which pull together a relatively large number of cases filed over a relatively long period of time. My sample included three
} 
(d) the total number of accused infringers against which each patent was asserted: the total number of unique parties against which an infringement claim has been filed or who filed claims seeking a declaration of relief therefrom; ${ }^{61}$

(e) litigation outcomes: whether each patent was ever adjudicated on the merits and, if so, whether the outcome was a finding of infringement, noninfringement, or invalidity; ${ }^{62}$ and

(f) suit-specific and assertion-specific statistics for litigation ongoing six years prior to expiration: the start date, date of resolution, and number of accused infringers for each suit ongoing within at least six years of the patent-in-suit's expiration, and the start date and date of resolution of each individual infringement claim in those suits.

\section{Assignment History and NPE Status}

In order to compare enforcement timing among practicing and nonpracticing patentees, I also collected information concerning each patent's owner, including:

(a) each patent's chain of ownership: the number of times each patent changed hands between the time it was issued and the time it was first asserted in court, including the dates of the first assignment after issue and the last assignment prior to litigation; ${ }^{63}$ and

MDLs. See In re Rembrandt Tech., LP Patent Litig, No. 07-MD-1848-GMS (D. Del.) (combining ten suits filed between September 2005 and November 2007); In re Acacia Media Tech. Corp., No. 05-MD-1114 (N.D. Cal.) (combining nineteen suits filed in 2004 and 2005); In re Pabst Licensing, GmbH Patent Litig., No. 99-MD-1298 (E.D. La.) (combining eight suits filed between March 1997 and July 2002).

${ }^{61}$ I excluded "John Doe" parties from this number.

62 I did not count default judgments as "adjudications." To make the most of extremely limited data, the litigation outcomes reported below reflect whether each studied patent was ever adjudicated on the merits at the district court level; it is not adjusted to account for appellate outcomes. Analysis of district court outcomes alone is not uncommon in the literature. Cf. Michael J. Mazzeo, et al., Excessive or Unpredictable? An Empirical Analysis of Patent Infringement Awards, at *28 (working paper 2011) (studying only district court damages awards). Litigation outcome data also reflects the fact that a small number of patents (four product-company patents and one NPE patent) were adjudicated multiple times with varying results.

${ }^{63}$ I obtained this data from the PTO's Assignment on the Web for Patents (AOTW-P), http://assignments.uspto.gov/assignments/?db=pat. Patent owners generally do, but are not required to, record assignments with the PTO. See Chien, Predicting Patent Litigation, supra note _, at $* 30$. Assignments recorded with the PTO within ninety days protect against ownership claims of subsequent purchasers. 35 U.S.C. $§ 261$. However, there are no other benefits or penalties. To ensure that my data reflects only true transfers of ownership, I excluded from this data any assignments that merely occurred as a result of an owner's name change or minor corporate reorganization. Also, in a number of instances, 
(b) the NPE status of each party asserting a patent: whether the entity asserting each patent sold a product and, if not, what kind of NPE it was.

For this purpose I adopted the patentee classification system developed by Mark Lemley and Nathan Myhrvold, which is outlined below in Table 2. Only Class 8 patentees - those that produce a product - are "practicing" entities. Patentees whose status I could not determine fall in Class 10 and were excluded from my sample. ${ }^{64}$ Strictly speaking, all other classes are "non-practicing" entities. Though NPEs are by no means a homogenous monolith, for simplicity's sake many of the results detailed below are reported for NPEs as a whole. Where practicable, however, results are broken down by entity class so the reader may determine for herself where to draw the line between NPEs and "trolls."

the party asserting a patent in litigation did not match the last-recorded owner on file with the PTO. In the vast majority of such cases, I was able to determine from pleadings or other litigation documents whether the party was an owner by unrecorded assignment or simply the last-recorded owner's exclusive licensee. I excluded from my calculations the few instances where I was unable to determine the party's status as owner or licensee.

${ }^{64}$ Following Allison, Lemley, and Walker, I exclude Class 10 patents from my study. However, as they note, "that a diligent search could not identify what an entity did suggests that it is likely some form of NPE." Patent Quality and Settlement, supra note _, at 6, n.28. I excluded three patents because I was unable to determine their owners' NPE statuses, and four individually-owned patents that were exclusively licensed to patentees of indeterminable NPE status. 
Table 2: Entity-Status Classes

\begin{tabular}{cl} 
Entity Class & \multicolumn{1}{c}{ Description } \\
\hline 1 & Acquired patents \\
2 & University heritage or tie \\
3 & Failed start-up \\
4 & Failed product company \\
5 & Individual-inventor-started company ${ }^{66}$ \\
6 & University, Government, or NGO $^{67}$ \\
7 & Start-up, pre-product \\
8 & Product company \\
9 & Individual inventor(s) \\
10 & Undetermined \\
11 & Industry Consortium \\
12 & IP subsidiary of a product company \\
\hline
\end{tabular}

Because many patents were owned at the time of suit by an entity of one class but actually asserted by an exclusive licensee of another, I identified each patent's owner and the party asserting each in litigation - i.e., the "patentee." Consistent with others in the literature, the results I report below compare the NPE status of the party acting as patentee in court, whether that party is the owner or exclusive licensee. ${ }^{68}$ Figure 1 below shows the variance between patent ownership and responsibility for enforcement. Notably, a significant number of NPE-owned patents were exclusively licensed to product producing patentees. All university-owned patents in my sample, and more than half of the individually-owned patents, were at the time of assertion exclusively licensed to product companies that

\footnotetext{
${ }^{65}$ There is a fine line between Class 1 and Classes 3 and 4 because many acquired patents come from failed product companies and start-ups. In this study, I categorized a patentee as Class 3 or Class 4 when the entity filing suit was the failed company itself, and Class 1 when the entity filing suit was a distinct IP-holding firm that acquired the patent, even if that firm's entire portfolio appeared to be salvaged from one failed company. For example, I categorized T.M. Patents, LP - a firm created to hold patent assets from the failed Thinking Machines Corp - as Class 1, not Class 4. Because there is only a minor distinction between a failed company that began to assert its patents in its own name and a failed company that first reorganized into an LLC or LP before doing the same, I report combined results below for Classes 1, 3-4.

${ }^{66}$ In this class, and in Class 9, I included patents owned by licensing companies started by deceased inventors' heirs and patents owned by such heirs, respectively. A number of patents were litigated by family members of the named inventor after the inventor's death. See, e.g., Black \& Decker, Inc. v. Billy Star Holdings, Ltd., No. 08-CV-1261 (D. Minn) (suit filed with deceased inventor's son controlling patent-owning entity).

${ }^{67}$ In my sample, all Class 6 patents were owned by universities.

${ }^{68}$ See Extreme Value, supra note _, at 10 (categorizing "the patent plaintiff").
} 
acted as plaintiffs or declaratory-judgment defendants. ${ }^{69}$ Firms organized for the purposes of exploiting unused patents - patent acquisition firms, firms holding the IP assets of failed companies, and inventor-affiliated licensing firms - therefore account for almost two-thirds of all NPE asserted patents. ${ }^{70}$ More controversial NPEs account for just a small minority of NPE patents and do not drive the results reported below. ${ }^{71}$

Finally, it is worth noting that my sample does not include any patents owned by Ronald Katz - i.e., Ronald A. Katz Technology Licensing, LP, a Class 5 patentee - or Jerome Lemelson - e.g., Lemelson Medical Education \& Research Foundation, also Class 5 - though several litigated patents owned by both were issued within the study period. ${ }^{72}$ Katz and Lemelson are perhaps the two most famous and most prolific patent plaintiffs of all time, and have what can conservatively be described as an outsized impact on patent litigation statistics. Both, and especially Katz, have a history of filing extremely large numbers of suits against extremely large numbers of accused infringers, and authors of previous studies have grappled with whether to exclude their statistics. ${ }^{73}$ The addition of even one Katz patent

\footnotetext{
${ }^{69}$ In addition, one individually-owned patent was asserted by a patent acquisition firm. Only one patent originally owned by a university found its way into the hands of another NPE. See BioTechnology, LLC v. CIBA Vision Corp., No. 09-CV-3947 (E.D. Pa.) (Drexel University joined as "involuntary plaintiff").

Additionally, a few patents (four total, or less than one percent of the entire sample) were transferred in between suits to entities of a different class. One patent initially asserted by a product company was later assigned to an IP-holding subsidiary. Another was asserted by a product company that subsequently failed and was reborn as a litigationoriented enterprise. A third was asserted by an individual inventor who later assigned the patent to an acquisition firm. And, a final patent was initially asserted by a start-up company that subsequently failed and assigned the patent to a patent acquisition firm. In order to compare litigation timing strictly across entity type, I divided these patents into multiple data points, one for each period of litigation supervised by a new entity type.

${ }^{70}$ See Ball \& Kesan, supra note , at *2 (noting that "licensing firms [are] the most common candidate for the 'troll' moniker"); Extreme Value, supra note _, at 24 (referring to "licensing companies in the business of buying up and enforcing patents" as " "trolls' by virtually anyone's definition"). Collectively, these patentee types account for 54 of 83 NPE-asserted patents, or 65.1\%. See Tbl. 7, infra. Patents acquired (from failed or operating companies) account for 35 of 83 , or $42.2 \%$. Patents asserted by inventoraffiliated licensing companies account for the remaining 19 of 83 , or $22.9 \%$.

${ }^{71}$ See supra note _. As discussed in greater detail infra, virtually all individuallyowned patents were asserted relatively early in the patent term and, therefore, also do not drive the results reported below.

${ }^{72} \mathrm{Katz}$ and Lemelson asserted at least 8 patents issued during the study period. U.S. Patent No. 5,297,197 (Katz); U.S. Patent No. 5,259,023 (same); U.S. Patent No. 5,255,309 (same); U.S. Patent No. 5,251,252 (same); U.S. Patent No. 5,224,153 (same); U.S. Patent No. 5,218,631 (same); U.S. Patent No. 5,283,641 (Lemelson); U.S. Patent No. 5,231,259 (same).

${ }^{73}$ In a study of patents litigated eight or more times between 2000 and 2007, Katz
} 
to my sample - e.g., U.S. Patent No. 5,255,309 or U.S. Patent No. $5,251,252$, both of which have been asserted in about eighty suits - would have significantly increased the per suit and per assertion results reported below.

Figure 1: Patent Owner - Patentee Histogram ${ }^{74}$

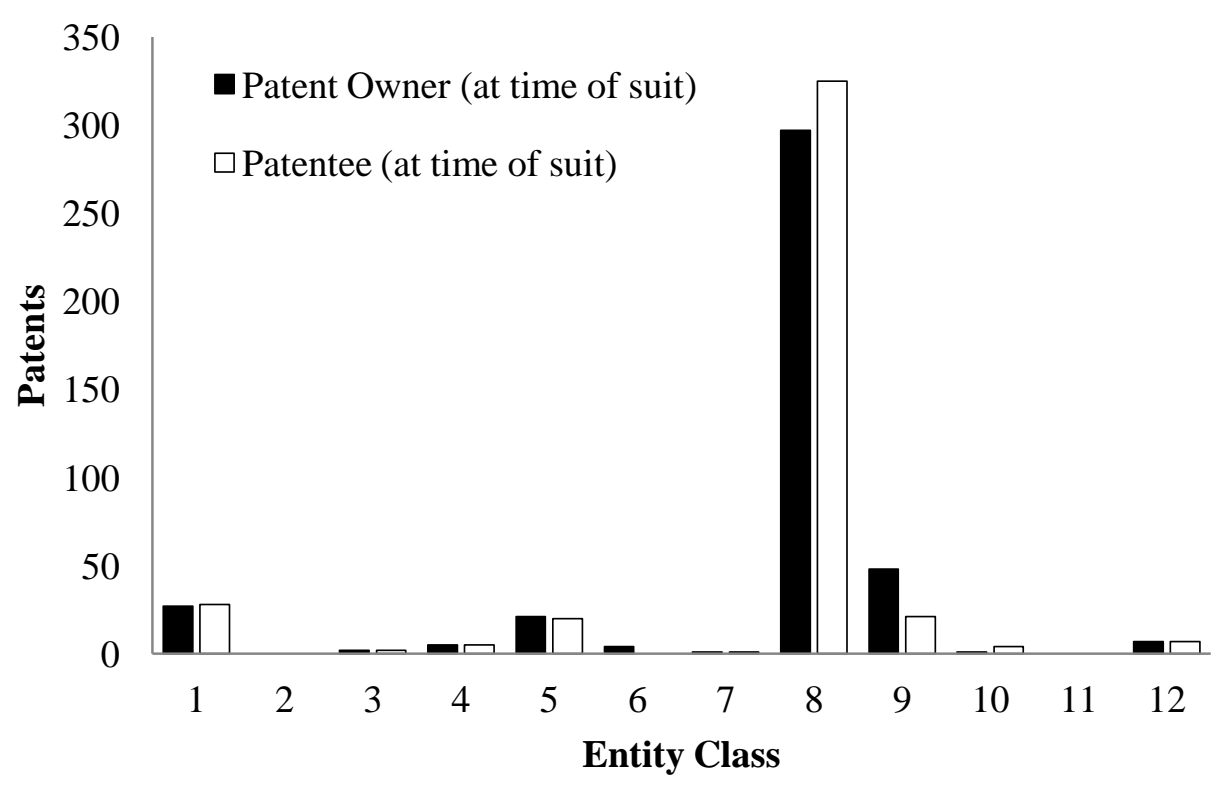

\section{Technology, Industry Category}

Lastly, I categorized each patent by technology focus and industry. Rather than use the PTO classification system, I followed Allison, Lemley, and Walker's taxonomy, which includes nine nonexclusive technology categories and thirteen nonexclusive industry categories listed below in Table $3 .^{75}$

alone accounted for $60 \%$ of all studied lawsuits. See Extreme Value, supra note _, at 26 (noting the enormity of the "Katz effect," but ultimately deciding to retain Katz-related statistics).

${ }^{74}$ These statistics generally comport with Colleen Chien's findings in a study of litigated patents issued in 1990, though I find a higher percentage of product companyasserted patents. See Chien, Predicting Patent Litigation, supra note _, at *31-32 (finding in a study of 667 litigated patents issued in 1990 that $73 \%$ were litigated by product companies, $9 \%$ by "patent assertion entities," and $18 \%$ by individual inventors). For the precise breakdown of NPE-asserted patents among the various classes, see Table 7, infra.

${ }^{75}$ Allison, Lemley, and Walker's taxonomy, is explained in detail at Extreme Value, supra note _, at 6-10. In prior work, Allison and Lemley have criticized the PTO's rather 
Table 3: Technology and Industry Areas

Technology Categories

1. Software

2. Pure software

3. Software business method

4. Mechanical

5. Electronics

6. Optics

7. Imaging

8. Biotechnology

9. Chemistry
Industry Categories

1. Computer

2. Semiconductor

3. Electronics

4. Medical

5. Pharmaceutical

6. Biotechnology

7. Chemical

8. Communications

9. Transportation

10. Energy and utility services

11. Financial

12. Consumer goods and services

13. Construction

Much of this data I have reserved for future research. I do, however, report results below that distinguish among "software," "high-tech," "medical device," "pharmaceutical," and "biotech" patents. Software patents, as used in this study, are those that fall within technology categories 1, 2, or 3, regardless of the industry in which they are employed. $^{76}$ I give the label "high-tech" to all patents covering computer, electronics, and/or telecommunications technology, including all software patents. These patents generally fall within one or more of technology categories 1-3 and 5-7 and one or more of industry categories 1-4, 8-9. Finally, medical device, pharmaceutical, and biotech patents are those that fall within industry categories 4, 5, and 6, respectively. Medical device patents touch on almost every technology category, though most are strictly or primarily mechanical in nature. Some medical device patents, for example those covering computer- or electronically-assisted medical procedures, overlap with technology categories 1-3 and 5-7.

byzantine classification system. Who's Patenting What? An Empirical Exploration of Patent Prosecution, 53 VAND. L. REV. 2099, 2114 (2000).

${ }^{76}$ Categories 2 and 3 are both subsets of category 1. Extreme Value, supra note _, at 6-7. 


\section{RESULTS}

\section{A. Two Patent Terms}

I begin by investigating the relative ages of patents asserted by practicing and non-practicing entities. To make this comparison, however, I must adjust for the fact that patents in my sample may have one of two different patent terms. Patents in this study issued just before a major event in the history of U.S. patent law: the United States' 1994 ratification of GATT/TRIPs. ${ }^{77}$ To comply with these new international obligations, Congress changed the way U.S. patent law calculates the patent term for the first time since 1952. ${ }^{78}$ Patent reform legislation effective June 8, 1995 altered the patent term from seventeen years from issue to twenty years from filing. ${ }^{79}$ Importantly for this study, this same legislation created a hybrid calculation for patents caught in this transition - i.e., unexpired patents issued before or pending on June 8, 1995, a group that includes every patent issued during the study period. ${ }^{80}$ These patents receive a term of either seventeen year from issue or twenty years from filing, whichever is longer. ${ }^{81}$

Thus, barring invalidation or a missed maintenance fee payment, every patent in this study received a term of at least 17 years from issuance and at least 20 years from filing. ${ }^{82}$ The percentage of patents falling in each category is shown below in Table 4 . With the average duration of prosecution among studied patents near three years - for product companies and NPEs alike - these two calculations provide a quite similar term of protection for the bulk of patents. ${ }^{83}$ Nonetheless, to account for these slight

${ }^{77}$ In full, the "General Agreement on Tariffs and Trade, including the Agreement on Trade Related Aspects of Intellectual Property Rights, Including Trade in Counterfeit Goods." See General Agreement on Tariffs and Trade, opened for signature Oct. 30, 1947, 61 Stat. A3, 55 U.N.T.S. 187; Agreement on Trade Related Aspects of Intellectual Property Rights, Including Trade in Counterfeit Goods of the General Agreement on Tariffs and Trade, opened for signature Apr. 15, 1994, 33 I.L.M. 81, 83-111 (1994).

78 The U.S. also committed to make this change in a contemporaneous executive agreement with Japan. See Lemley, An Empirical Study of the Twenty-Year Patent Term, supra note _, at 370, n.7.

${ }^{79}$ Compare 35 U.S.C. $§ 154$ (1995) with 35 U.S.C. $§ 154$ (1988).

${ }^{80} 35$ U.S.C. $\$ 154(c)(1)$.

${ }^{81} I d$.

${ }^{82}$ Patents that issued from applications less than three years' old receive a longer term under the 20-years-from-filing formulation. Patents that issued from applications spending longer than three years at the PTO received a longer term under the 17-years-from-issue formulation.

${ }^{83}$ On average product company patents spent 1,095 days (exactly 3 years) at the PTO; NPE patents spent 1,112 days on average, just over two weeks longer. 
variations in patent term, I primarily report patent age measured in years prior to expiration, whether 17 years from issue or 20 years from filing. ${ }^{84}$

\section{Table 4: Patent Term}

\begin{tabular}{ccc} 
Event & \multicolumn{2}{c}{ Percentage of Patents } \\
& Possible Term & Actual Expiration \\
\hline 20-years from filing & $68.5 \%$ & $55.7 \%$ \\
17-years from issue & $31.5 \%$ & $25.7 \%$ \\
Failure to pay & - & $14.7 \%$ \\
maintenance fee & & \\
Invalidated & - & $3.9 \%$ \\
\hline
\end{tabular}

\section{B. Per Patent}

Figures 2 and 3 below show the relative timing of patent enforcement across NPE status on a per patent basis. Figure 2 is a histogram of the dates on which patents were litigated for the first time, measured backward from the date each patent's term ended. Figure 3 is a histogram of the dates on which litigation asserting patents ended once and for all, again measured backward from patents' expiration. The results are dramatic. As shown below in Table 5, on average product companies finish enforcing their patents before NPEs even begin.

It is clear from these Figures that product company litigation and NPE litigation follow opposing trends. Product companies overwhelmingly begin litigating their patents early in the patent term, on average more than 12 years before expiration, ${ }^{85}$ and overwhelmingly finish with many years of patent life remaining, on average more than $9 .{ }^{86}$ NPEs, on the other hand, begin litigating their patents much later in the term, less than 9 years from expiration on average, ${ }^{87}$ and overwhelmingly finish in the final few years of the patent term, with on average about 4.5 years (and a median of under 3 years) remaining. ${ }^{88}$

${ }^{84}$ When measuring backwards from expiration, I use the date the term expired or would have expired for patents that fell into the public domain prematurely.

${ }^{85} 12.23$ years, with a standard deviation of 4.31 years and a median of 12.7 years.

${ }^{86} 9.42$ years, with a standard deviation of 4.73 years and a median of 9.92 years.

${ }^{87} 8.84$ years, with a standard deviation of 4.75 years and a median of 8.46 years.

${ }^{88} 4.56$ years, with a standard deviation of 4.78 years and a median of 2.79 . These statistics are comparable to prior estimates. See Risch, supra note _, at 27 (finding, among the most litigious NPEs, an average delay of 8.5 years between issue and filing a first complaint); John R. Allison \& Mark A. Lemley, Empirical Evidence on the Validity of Litigated Patents, 26 AIPLA Q.J. 185, 237 (1998) (finding that patent suits, on average, are resolved 12.3 years from the application date of the patent-in-suit). 
These opposing trends intersect one another about three to five years prior to expiration. With five years of patent life remaining, product companies have started (and in most cases finished) litigating over $94 \%$ of their patents, while over $30 \%$ of NPE patents have not yet been asserted. With three-and-a-half years of term remaining, product companies have finished asserting more than $86 \%$ of their patents, while more than $59 \%$ of NPE patents remain in, or will soon enter, the court system. Though just one-fifth of all patentees, NPEs asserted almost $57 \%$ of patents litigated for the first time within five years of expiration and over $65 \%$ of patents in litigation resolved within three-and-a-half years of expiration.

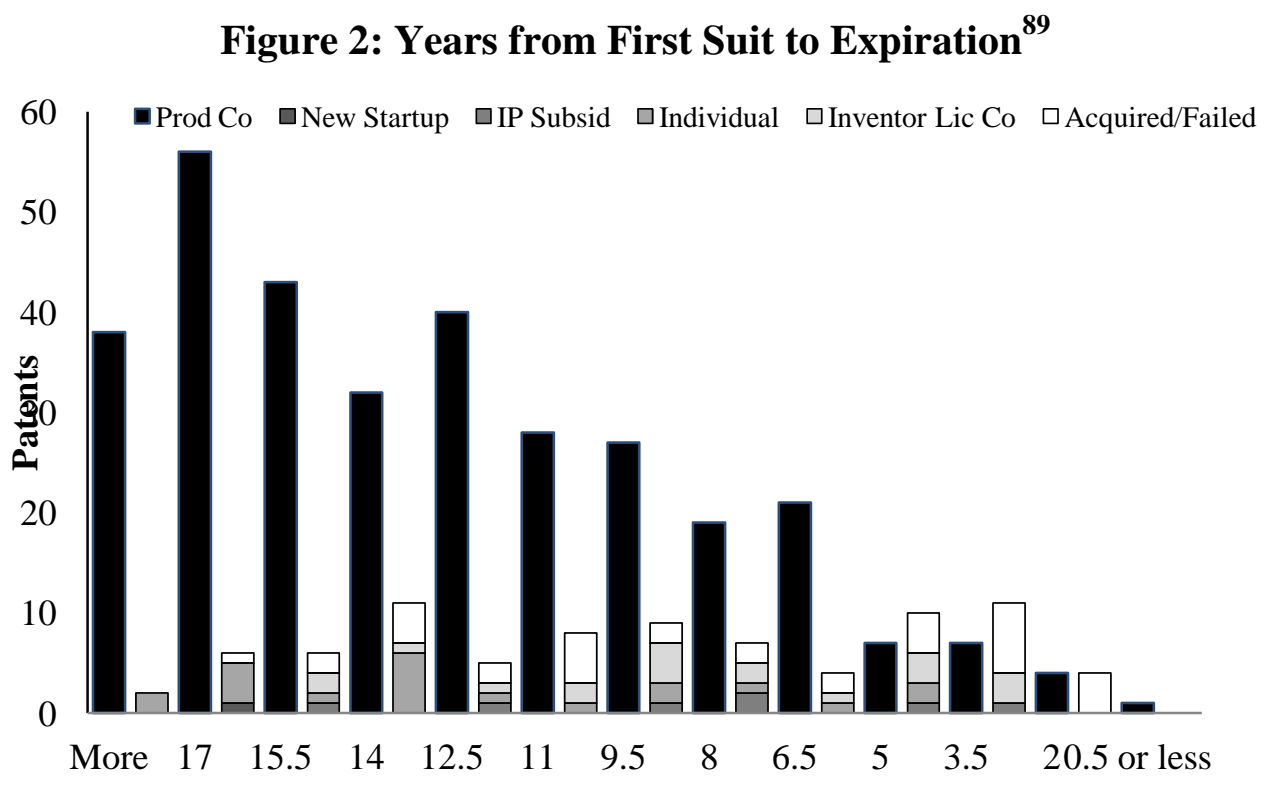

Years Until Expiration

\footnotetext{
${ }^{89}$ For a breakdown of specific findings across patentee classes and the patent term, see Table 7, infra.
} 
Figure 3: Years from Cessation of All Litigation to Expiration

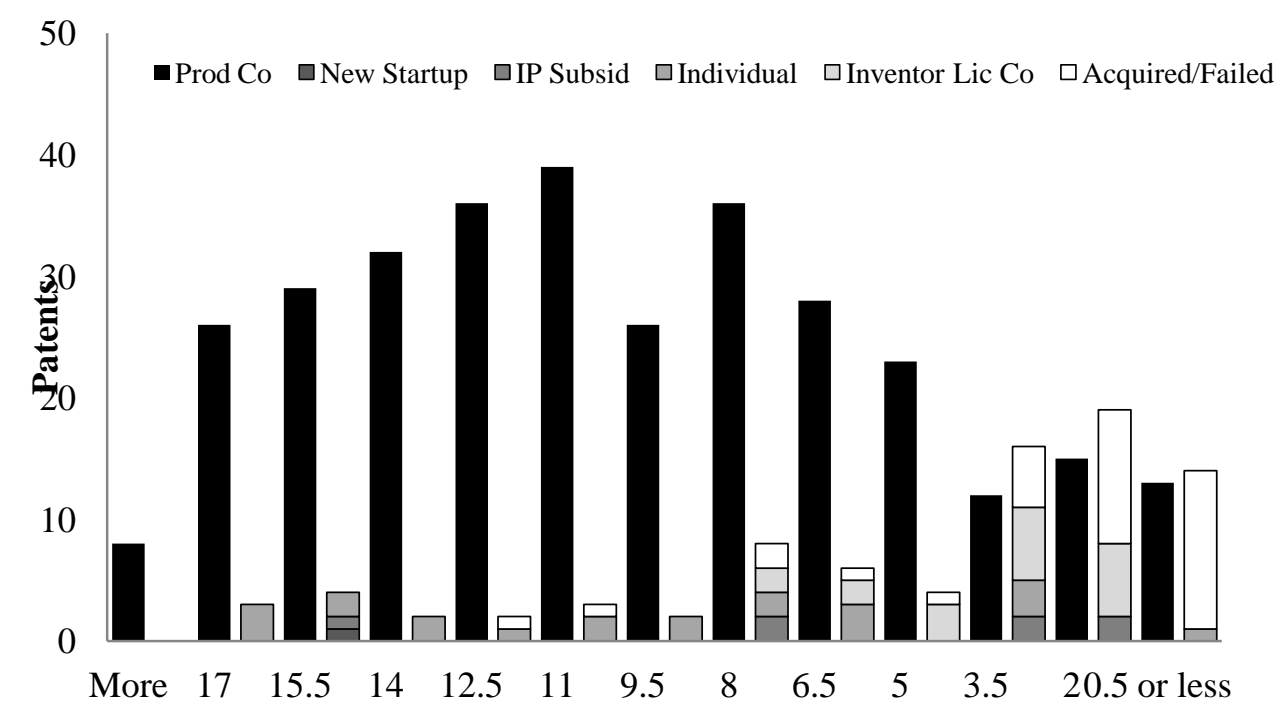

Years Until Expiration

Data on the chain of ownership of these litigated patents, also reported below in Table 5, sheds some light on NPEs' relatively long delay in filing suit. NPE asserted patents, particularly those acquired from other firms (failed or otherwise), change hands more frequently over a longer period of time than their counterparts litigated by product companies. Moreover, once they reach the patentee who will ultimately assert them in court, NPE asserted patents sit for another three-and-a-half years on average before litigation is filed.

As a whole, NPE-asserted patents are three times more likely to have changed hands between issue and enforcement. ${ }^{90}$ Classes 1,3 and 4 , collectively, are more than four times as likely to have been transferred between owners post-issue and, among assigned patents, have changed hands roughly $50 \%$ more times per patent. Patents do not reach acquisition firms until about nine years after issue, and these firms wait almost three additional years on average before filing suit. Other NPEs fare little better. Inventor-affiliated licensing companies generally do not form until about six years after issue and, on average, wait more than five additional years before filing suit. And, patents reach product companies' licensing

${ }^{90}$ These statistics likely understate the variance in rates at which product-company and NPE patents are sold because many product company assignments are the result of mergers, acquisitions and spin-offs involving all the patent owner's assets, not just its patent rights. See Chien, Predicting Patent Litigation, supra note _, at *24. 
subsidiaries on average about eight years after issue and sit for an additional four years before assertion. Individual inventors, by contrast, file suit quickly on almost the exact same timeline as product companies.

Thus, with the notable exception of those litigated by individuals, NPE asserted patents take a long, circuitous path from the PTO to the courthouse that covers more than a decade and includes more than two prior owners. This finding strongly suggests that it makes little sense to discuss the percentage of NPE litigation among all suits filed. NPEs do not obtain patents until the patent term is half-spent and hold their patents for years more before filing suit, perhaps while waiting for emerging industries to mature. ${ }^{91}$ Thus, the bare statistic that NPEs account for only about one-fifth of all patents litigated obscures the fact that NPEs account for the majority of patents litigated in the final few years of the term - the only portion of the term when they are active.

Table 5: Litigation Timing, Per Patent, and Assignment History

\begin{tabular}{|c|c|c|c|c|c|c|c|}
\hline & $\begin{array}{l}\text { Prod Co } \\
(\text { Class 8) } \\
\end{array}$ & All NPEs & $p$-value ${ }^{92}$ & $\begin{array}{c}\text { Acquired/Failed } \\
\text { (Classes 1, 3-4) }\end{array}$ & $\begin{array}{c}\text { Inventor Lic Co } \\
\text { (Class 5) }\end{array}$ & $\begin{array}{c}\text { Individual } \\
\text { (Class 9) }\end{array}$ & $\begin{array}{l}\text { IP Subsid } \\
\text { (Class 12) } \\
\end{array}$ \\
\hline \multicolumn{8}{|l|}{ Avg litigation start: } \\
\hline Until expiration & $12.2 \mathrm{yrs}$ & 8.8 & $<0.001$ & 7.32 & 7.92 & 12.2 & 8.02 \\
\hline From issue & $5.6 \mathrm{yrs}$ & 8.9 & $<0.001$ & 10.2 & 9.96 & 5.6 & 10.1 \\
\hline From filing & $8.6 \mathrm{yrs}$ & 11.9 & $<0.001$ & 13.69 & 12.42 & 8.56 & 12.41 \\
\hline \multicolumn{8}{|l|}{ Avg litigation end: } \\
\hline Until expiration & $9.4 \mathrm{yrs}$ & 4.6 & $<0.001$ & 1.99 & 3.27 & 9.26 & 5.29 \\
\hline From issue & $8.4 \mathrm{yrs}$ & 13.2 & $<0.001$ & 15.53 & 14.59 & 8.53 & 12.83 \\
\hline From filing & $11.4 \mathrm{yrs}$ & 16.2 & $<0.001$ & 19.02 & 17.05 & 11.5 & 15.15 \\
\hline Percent assigned $^{93}$ & $20 \%$ & $62 \%$ & $<0.001$ & $86 \%^{94}$ & $71 \%$ & $14 \%^{95}$ & $80 \%$ \\
\hline \multicolumn{8}{|l|}{ Avg, per assigned: } \\
\hline Total \# assigns & 1.45 & 1.94 & $<0.001$ & 2.1 & 1.67 & 1 & 2.25 \\
\hline Issue to $1^{\text {st }}$ assign & $3.9 \mathrm{yrs}$ & 5.4 & 0.013 & 5.7 & 4.1 & 7.2 & 5.8 \\
\hline $1^{\text {st }}$ to last assign & $1.5 \mathrm{yrs}$ & 2.4 & 0.030 & 3.0 & 1.7 & 0 & 1.9 \\
\hline last assign to assert & $2.9 \mathrm{yrs}$ & 3.5 & 0.056 & 2.8 & 5.2 & 2.3 & 3.9 \\
\hline
\end{tabular}

${ }^{91}$ Again, my findings comport with prior estimates in the literature. Risch, supra note , at 28 (finding that, among patents asserted by the ten most litigious NPEs, "[t]he mean time between patent issuance and the last assignment recorded98 was 2581 days (7.07 years)"); see also Mann, supra note _, at 1027.

92 Unless indicated otherwise, all $p$-values were calculated using the Pearson's chisquare test function of Stata v.11.1.

93 As explained above, these statistics attempt to count only "true" transfers of ownership, not mere name changes or minor corporate reorganizations (both of which appear in PTO assignment records).

${ }^{94}$ The rate is not $100 \%$ because five patents remained in the name of their failed owner.

${ }^{95}$ The rate is not $0 \%$ because there were three assignments between joint inventors i.e., to consolidate ownership in one inventors' name. 


\section{Per Suit and Per Assertion}

In fact, the results reported above also understate the true magnitude of late-term NPE enforcement. As shown below in Table 6, NPEs are far more litigious on average than product companies. Overall, NPEs file more than twice as many suits per patent and assert each patent against more than four times as many alleged infringers. Moreover, NPEs are even more litigious with patents asserted especially late in the patent term. Per patent litigated in the last two years of its term, NPEs file more than three additional suits against almost seventeen additional infringers. ${ }^{96}$

Table 6: Relative Litigiousness

\begin{tabular}{|c|c|c|c|}
\hline & Product Co. & NPE & $p$-value \\
\hline \multicolumn{4}{|l|}{ Overall: } \\
\hline Suits/Patent ${ }^{97}$ & 1.5 & 3.4 & $<0.001$ \\
\hline Assertions/Patent & 2.9 & 11.8 & $<0.001$ \\
\hline \multicolumn{4}{|c|}{ Lit complete, > 2 yrs from exp: } \\
\hline Suits/Patent & 1.4 & 1.6 & \\
\hline Assertions/Patent & 2.7 & 5.1 & \\
\hline \multicolumn{4}{|c|}{ In lit, $<2$ yrs from exp: ${ }^{98}$} \\
\hline Suits/Patent & 2.5 & 6.0 & \\
\hline Assertions/Patent & 5.0 & 21.9 & \\
\hline \multirow[t]{2}{*}{$p$-value } & $<0.001$ & 0.008 & \\
\hline & $<0.001$ & 0.020 & \\
\hline
\end{tabular}

Taking into account NPEs' relative litigiousness, NPEs' dominance of late-term patent litigation grows considerably, as does their share of all suits and all assertions. Figure 4 below is a histogram of lawsuit filing dates for all suits filed within 6 years of the patent-in-suit's expiration. ${ }^{99}$ Figure 5 is a histogram of lawsuit end dates for all suits resolved within 6 years of the patent-in-suit's expiration. Both show a significant increase in NPEs' late-

${ }^{96}$ Naturally, both product companies and NPEs assert their oldest patents still in litigation more times than average.

${ }^{97}$ Some studied patents were asserted together in the same suit, and all "per suit" data reported infra accounts for this fact. The rates reported in this Table, however, report the average number of suits in which each patent was asserted, whether or not another studied patent was asserted in the same suit.

${ }^{98}$ Results are not uniformly significant at three years and beyond. At two-and-a-halfyears, results are all significant at a 93\% confidence level or better (i.e., $p$-value < 0.07).

${ }^{99}$ In future versions of this study, I plan to extend this data back beyond six years. 
term domination viewed on a per suit basis. NPEs account for the majority of all new patent filings in four of the last five years of the patent term and account for more than $62 \%$ of all patent suits filed within five years of the patent-in-suit's expiration. NPEs similarly account for the majority of patent suits resolved within each of the last four years of the patent term and account for more than $67 \%$ of all patent suits resolved within three years of the patent-in-suit's expiration.

Figure 4: Years from Each Suit's Filing to Patent-in-Suit's Expiration

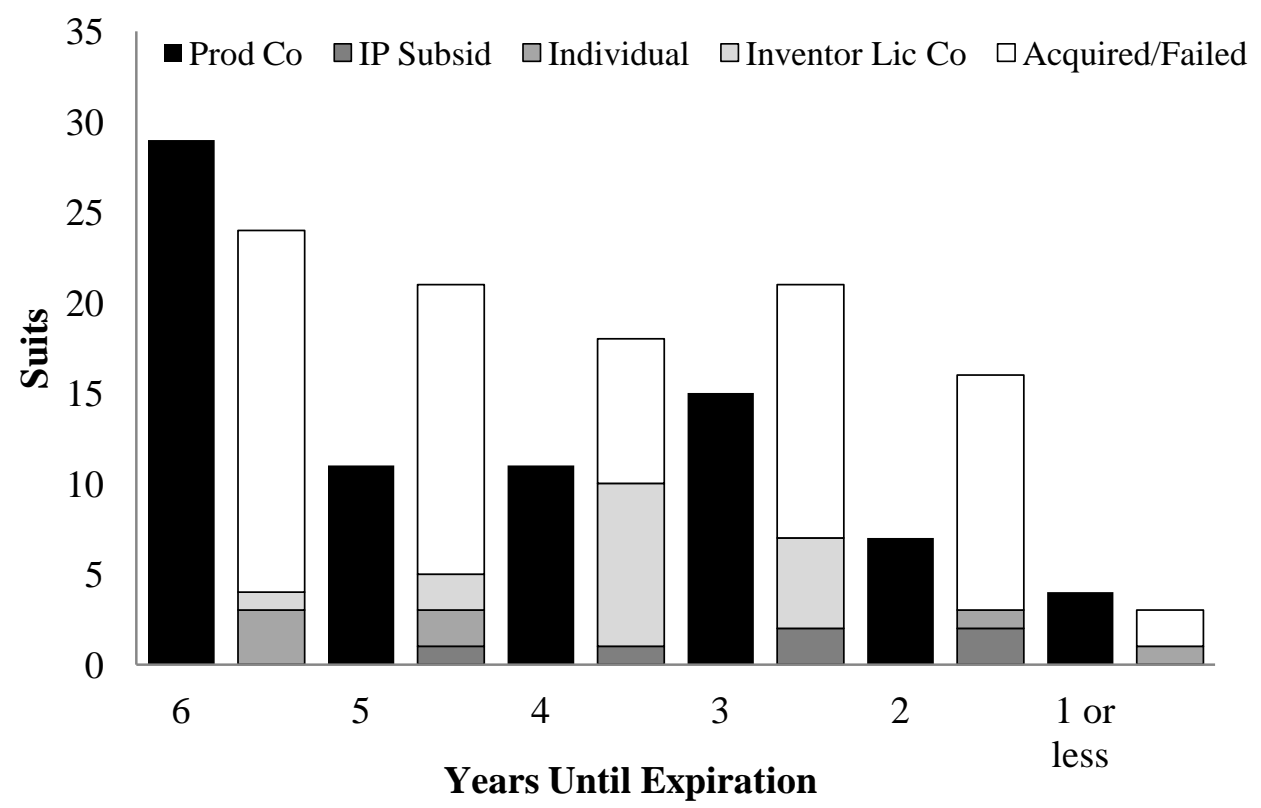


Figure 5: Years from Each Suit's Resolution to Patent-in-Suit's Expiration

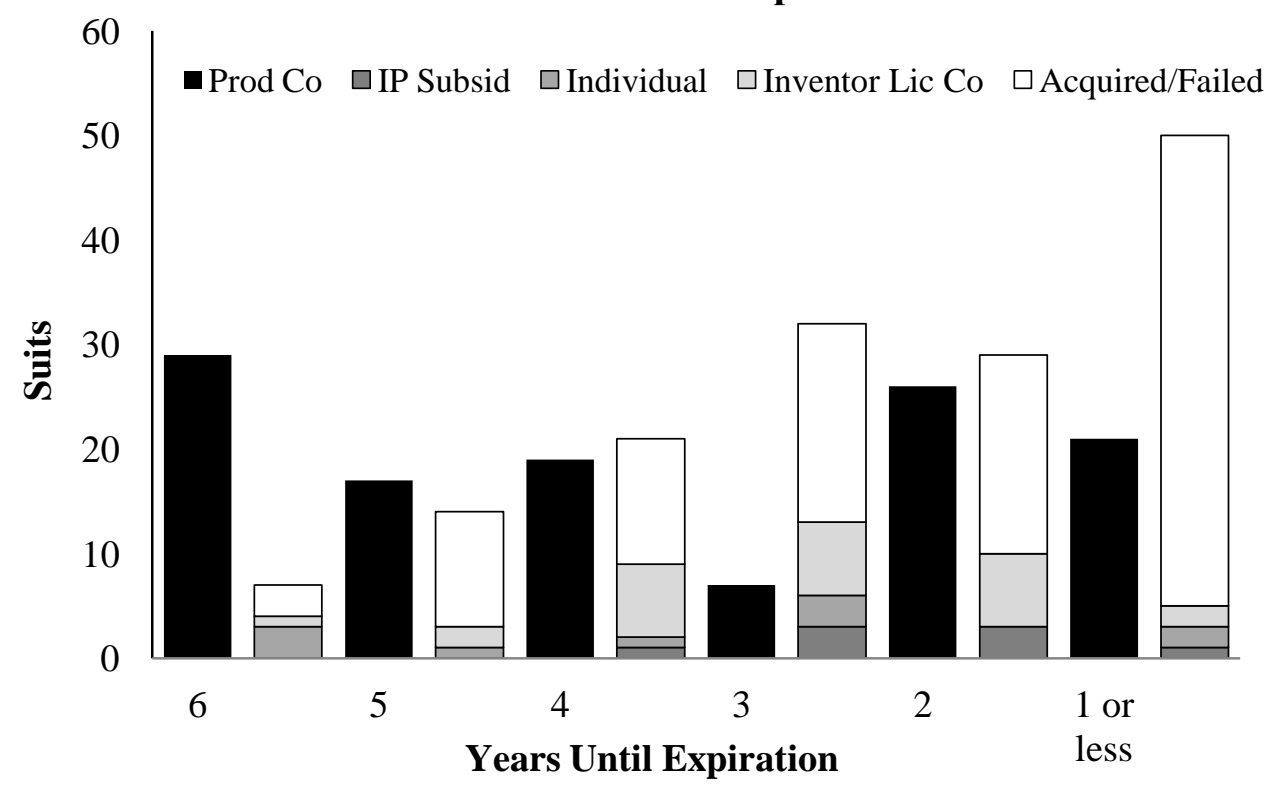

Finally, viewed per accused infringer - or per "assertion" - NPEs' domination of late-term patent litigation becomes even more overwhelming. Figure 6 below is a histogram of filing dates for all assertions filed within 6 years of the asserted patent's expiration. Figure 7 is a histogram of resolution dates for all assertions resolved within six years of the patent-insuit's expiration. The results shown in both figures are especially dramatic. NPEs account for the majority of all new patent assertions in each of the last six years of the patent term and account for more than $82 \%$ of all patent assertions filed within five years of the patent-in-suit's expiration. NPEs similarly account for the majority of patent assertions resolved within each of the last five years of the patent term and account and more than $82 \%$ of all patent assertions resolved within three years of expiration. 
Figure 6: Years from Each Assertion's Filing to Patent-in-Suit's Expiration

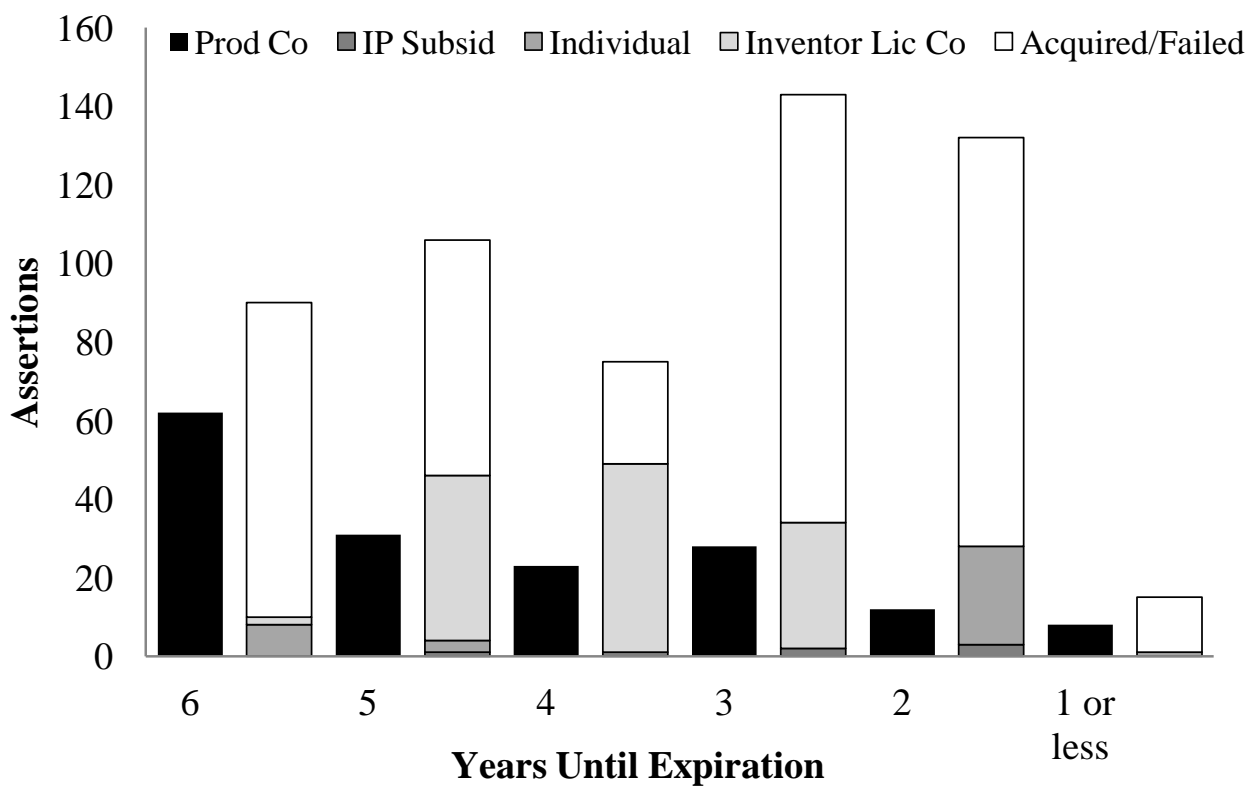

Figure 7: Years from Each Assertion's Resolution to Patent-in-Suit's Expiration

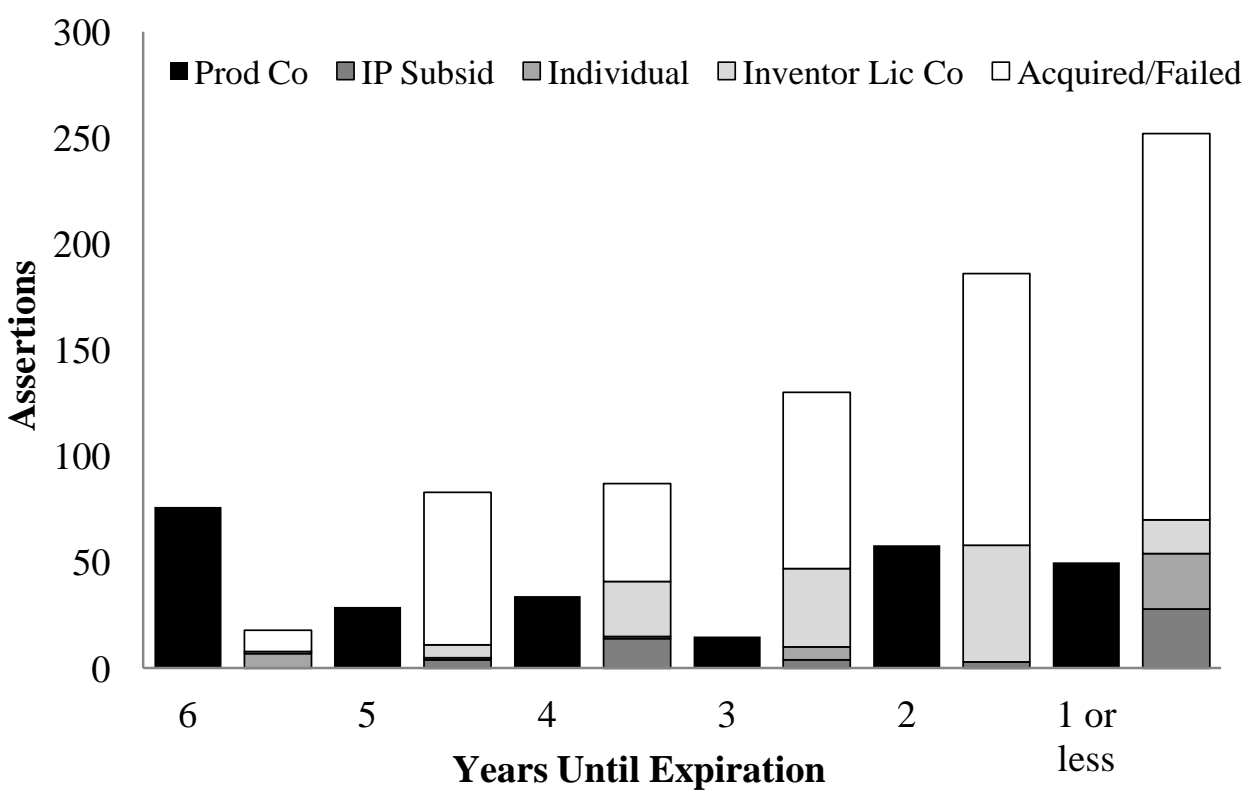

As summarized below in Table 7, properly viewed among all patents litigated at a similar age (rather than all litigated patents), NPE-asserted 
patents are the overwhelmingly dominant source of patent litigation in the final years of the patent term. NPEs assert the majority of new patents, file about two-thirds of new suits, and file over four-fifths of new assertions in the final five years of the patent term, and are responsible for virtually identical percentages of patents enforced, and suits and assertions resolved, within three years of expiration. Moreover, the lionshare of late-term NPE litigation is brought by patent acquisition firms, firms holding the IP remnants of failed companies, and inventor-affiliated licensing firms. Collectively, these classes account for about $90 \%$ of NPE suits ongoing within three years of the patent-in-suit's expiration. Thus, while prior studies may have shown that NPEs file "a small fraction of all patent infringement suits," 100 my results indicate that NPEs, and precisely those NPEs most associated with litigation abuse, ${ }^{101}$ are responsible for an enormous fraction of infringement claims brought late in the patent term, precisely when litigation abuse seems most likely. ${ }^{102}$

Table 7: Late-Term Litigation Summary

\begin{tabular}{|c|c|c|c|c|c|c|c|c|}
\hline & $\begin{array}{l}\text { Prod Co } \\
\text { (Class 8) }\end{array}$ & All NPEs & $p$-value & $\begin{array}{c}\text { Acquired/Failed } \\
\text { (Classes 1, 3-4) }\end{array}$ & $\begin{array}{c}\text { Inventor Lic Co } \\
\quad(\text { Class 5) }\end{array}$ & $\begin{array}{l}\text { New Startup } \\
\text { (Class 7) }\end{array}$ & $\begin{array}{c}\text { Individual } \\
\text { (Class 9) }\end{array}$ & $\begin{array}{l}\text { IP Subsid. } \\
\text { (Class 12) }\end{array}$ \\
\hline Total Patents & 326 & 83 & & 35 & 19 & 1 & 21 & 7 \\
\hline $\begin{array}{c}\text { Enforcement ceased } \\
\text { w/in } 3 \text { yrs of exp }\end{array}$ & 32 & 45 & $<0.001$ & 28 & 12 & 0 & 2 & 3 \\
\hline $\begin{array}{l}\text { Enforcement initiated } \\
\text { w/in } 5 \text { yrs of exp }\end{array}$ & 19 & 25 & $<0.001$ & 15 & 6 & 0 & 2 & 2 \\
\hline Total Suits ${ }^{103}$ & 447 & 253 & & 161 & 42 & 1 & 36 & 13 \\
\hline $\begin{array}{l}\text { Suits resolved } \\
\text { w/in } 3 \text { yrs of exp }\end{array}$ & 54 & 111 & $<0.001$ & 83 & 16 & 0 & 5 & 7 \\
\hline $\begin{array}{l}\text { Suits filed } \\
\text { w/in } 5 \text { yrs of exp }\end{array}$ & 48 & 79 & $<0.001$ & 53 & 16 & 0 & 4 & 6 \\
\hline Total Assertions & 949 & 978 & & 655 & 179 & 3 & 81 & 60 \\
\hline $\begin{array}{c}\text { Assertions resolved } \\
\text { w/in } 3 \text { yrs of exp }\end{array}$ & 123 & 568 & $<0.001$ & 393 & 108 & 0 & 32 & 35 \\
\hline $\begin{array}{l}\text { Assertions filed } \\
\text { w/in } 5 \text { yrs of exp }\end{array}$ & 102 & 471 & $<0.001$ & 313 & 122 & 0 & 29 & 7 \\
\hline
\end{tabular}

\section{Technology Areas and Litigation Outcomes}

The results reported above suggest that the final few years of the patent term primarily benefit NPEs. Compared to product companies, NPEs as a whole, and especially firms that hold patents purely for enforcement, assert

100 See supra note_.

${ }^{101}$ See supra note ${ }^{-}$.

${ }^{102}$ See Risch, supra note _, at 27 (noting that "the longer [NPEs] wait, the more like trolls their behavior might appear"').

103 This data was adjusted to account for the fact that some studied patents were asserted together in one suit. 
more patents, in more suits, and against more accused infringers late in the patent term. In fact, as Table 6 shows, NPEs actually become more aggressive as their patents age. NPE status and sheer litigiousness, however, are not the only traits commonly associated with patent "trolls." In this section, I investigate the prevalence of two other common trollrelated characteristics: a fondness for asserting high-tech patents and a penchant for losing when forced to adjudicate their infringement claims on the merits.

In essence, these statistics further measure the extent to which NPEs take advantage of the tail end of the patent term. Product lifecycles in the high-tech industry are notoriously short. Computing power, after all, doubles roughly every two years. ${ }^{104}$ Thus, high-tech patents are by far the most likely to be grossly out of date - technologically speaking - when asserted close to two decades after their filing date. Additionally, the rate at which NPEs prove their infringement allegations gives some indication whether NPEs are relying on particularly strained claim interpretations to stretch aging patents so that they arguably cover more advanced technology.

Data on the diversity of litigated patents, shown below in Table 8, shows that high-tech patents play an out-sized role in NPE litigation, and in late-term litigation as a whole. Overall, about $64 \%$ of NPE-asserted patents cover computer- or electronics-related inventions, and almost $40 \%$ cover software-related inventions. ${ }^{105}$ By contrast, just over $40 \%$ of product company-asserted patents cover high-tech inventions and just $25 \%$ cover software-related subject matter. ${ }^{106}$ On a per suit and per assertion basis, the high-tech share of product company litigation remains roughly steady, while the high-tech share of NPE litigation jumps to $80 \%$ of suits and just under $80 \%$ of assertions. ${ }^{107}$

104 This observation, which has held true for decades, is known as "Moore's Law." See Gordon E. Moore, Cramming More Components Onto Integrated Circuits, ElECTRONICS, Apr. 19, 1965, at 114, 115 (predicting that computing power will double approximately every two years).

${ }^{105}$ Michael Risch, who used PTO classification numbers to define high-tech subject matter, found that $36 \%$ of patents asserted by the ten most litigious NPEs were high-tech inventions. Risch, supra note _, at 18 (finding also that the majority of high-tech patents in his study were software patents).

106 The variance between product companies' and NPEs' enforcement of software patents is statistically significant per patent $(p$-value $=0.007)$, per suit $(p$-value $<0.001)$, and per assertion ( $p$-value $<0.001)$. The variance between product companies' and NPEs' enforcement of other high-tech patents is (barely) statistically significant at the $90 \%$ confidence level per patent $(p$-value $=0.096)$ and not statistically significant per suit, but is significant per assertion ( $p$-value $=0.006)$.

107 As shown below in Table 8, the variance between product companies' and NPEs' share of all four technology categories is only statistically significant on a per assertion basis (software $p$-value $<0.001$; other high-tech $p$-value $=0.006$; medical device $p$-value $<$ 
Among patents asserted in the final three years of their term, the rate of high-tech subject matter increases - surprisingly, for all patentees. That is, high-tech patents account for an outsized percentage of patent claims filed by product companies and NPEs alike. ${ }^{108}$ In fact, in the final three years of the patent term, the high-tech gap between NPEs and product companies narrows considerably - not because the high-tech share of NPE litigation shrinks (it grows to $86 \%$ of assertions ${ }^{109}$ ), but rather because the high-tech share of product company litigation skyrockets to exceed $72 \%$ of assertions. ${ }^{110}$

Finally, turning to data on litigation outcomes shown below in Table $9,{ }^{111}$ I find that NPEs lose at a higher rate than product companies when their infringement claims are adjudicated and, again, that this variance increases among patents litigated late in the term. Because so few patents were adjudicated, however, the statistical significance of these findings is less than ideal. ${ }^{112}$ Overall, more than $56 \%$ of adjudicated NPE patents were found not infringed by a judge or jury, compared to just under $30 \%$ of adjudicated product company patents. ${ }^{113}$ Similarly, product companies

0.001; biotech-pharmaceutical $p$-value $<0.001$ ).

108 The prevalence of high-tech litigation in the final few years of the patent term, together with the large share of NPE litigation involving high-tech products, could suggest that my litigation timing findings merely reflect the fact that high-tech patents tend to be litigated late in the patent term. My data directly contradicts this hypothesis, however. Product companies asserting high-tech patents litigate those patents far earlier than their NPE counterparts. Among all high-tech patents, I find that product companies begin enforcement with an average of 11.72 years of patent term remaining, while NPEs begin with just 8.79 years remaining. This difference is statistically significant ( $p$-value $=0.039$ ). Among the same group of patents, product companies finish enforcement with an average of 9.38 years of term remaining, while NPEs conclude their enforcement efforts with just 3.72 years of term left. Again, this difference is highly statistically significant ( $p$-value < 0.001). Looking at software patents only, I find similar results. On average, product companies begin enforcement with 11.97 years of term remaining and finish with 8.84 years of term left. On average, NPEs begin with 9.34 years of term remaining and conclude just 3.19 years before expiration. The variance of both statistics is significant at a $90 \%$ confidence interval or better ( $p$-value $=0.095$ and $p$-value $=0.001$, respectively).

${ }^{109}$ This growth is statistically significant among software claims $(p$-value $=0.005)$ and among other high-tech claims ( $p$-value $=0.001)$.

${ }^{110}$ While growth in the number of product-company software claims is not statistically significant, growth in the number of other high-tech claims is highly significant ( $p$-value < $0.001)$. Growth in the number of product-company high-tech suits is also significant ( $p$ value $<0.001)$; growth in the number of high-tech patents enforced by product-companies is significant only at a $94 \%$ confidence level $(p$-value $=0.059)$.

${ }_{111}$ Again, the data in Table 9 reports whether each patent was ever found infringed, not infringed, or invalid at the district court level before appeal. See supra note .

${ }^{112}$ A substantial percentage of late-filed suits are still ongoing, and may well add data in the coming months that will strengthen (or weaken) these results.

${ }^{113}$ As shown below in Table 9, this difference is statistically significant. 
proved infringement of almost half their adjudicated patents, while NPEs proved infringement of just a quarter. ${ }^{114}$ Moreover, the variance between product companies' and NPEs' success at proving infringement grows with time, though not because NPEs become worse (to a statistically significant degree anyway). Rather, product companies become more successful. Among adjudicated patents litigated in the final three years of the patent term, product companies proved infringement of $70 \%$, a statistically significant increase at a $92 \%$ confidence level, ${ }^{115}$ while NPEs fail to prove infringement or establish validity of greater than $70 \% .^{116}$

${ }^{114}$ This variance is only significant at a 90\% confidence level ( $p$-value $\left.=0.091\right)$. Also, note that I do not count default judgments as "adjudications."

${ }^{115}$ Chi-square $p$-value $=0.076$; Fisher's exact $p$-value $=0.074$.

116 One NPE asserted patent was found both invalid and not infringed. One possible confounding factor here is that, over time, it has become easier for accused infringers to locate prior art that restricts patentees' ability to advance broad claim interpretations. See, e.g., F. Russell Denton, Plumb Lines Instead of a Wrecking Ball: A model for Recalibrating Patent Scope, 16 J. INTELl. PROP. L. 1, 24 (2008) (noting that prior art searching "has become easier because of advances in search technology, online bandwidth, a growth industry in database searches . . . , and the appearance of free searchable PTO online databases, not to mention other public online databases."); $c f$. Allison \& Lemley, The Growing Complexity, supra note _, at 138 (discussing how computer searching may have improved patent examiners' ability to locate prior art). Note, however, that the invalidity rates reported below in Table 9 do not appear to support this hypothesis. 
Table 8: Technology Areas

\begin{tabular}{|c|c|c|c|c|c|c|}
\hline & \multicolumn{3}{|c|}{ Product Co. } & \multicolumn{3}{|c|}{ NPE } \\
\hline & Patent & Suit & Assertion & Patent & Suit & Assertion \\
\hline & & & & $* p$-value & $05 * 0$. & $1 \mathrm{e}>0.05^{117}$ \\
\hline \multicolumn{7}{|c|}{ 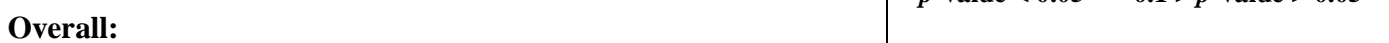 } \\
\hline$\%$ software & 24.9 & 21 & 21.5 & $39.8 *$ & $62.8 *$ & $57.2 *$ \\
\hline$\%$ other high-tech & 16.3 & 15.7 & 16.3 & $24.1 * *$ & 17 & $21.3 *$ \\
\hline$\%$ medical device & $8.6^{118}$ & 7.2 & 10.8 & $13.3^{119}$ & 5.1 & $5.9 *$ \\
\hline$\%$ bio-pharma & 5.5 & 6.9 & 6.1 & $0 *$ & $0 *$ & $0 *$ \\
\hline & & & & \multicolumn{3}{|c|}{$* p$-value $<0.05 * * 0.1>p$-value $>0.05^{12}$} \\
\hline \multicolumn{7}{|c|}{$\begin{array}{l}\text { Lit complete, > } 3 \text { yrs from } \\
\text { exp: }\end{array}$} \\
\hline$\%$ software & 24.4 & 20.6 & 21.2 & 31.6 & 62 & 52 \\
\hline$\%$ other high-tech & 15.1 & 12.7 & 11.5 & 23.7 & 16.2 & 16.1 \\
\hline$\%$ medical device & 8.3 & 7.1 & 11.7 & 10.5 & 5.6 & 4.9 \\
\hline$\%$ bio-pharma & 4.5 & 5.1 & 4.6 & 0 & 0 & 0 \\
\hline \multicolumn{7}{|c|}{ In lit, < 3 Yrs from exp: } \\
\hline$\%$ software & 28.1 & 24.1 & 23.6 & 46.7 & 64 & $60.9 *$ \\
\hline$\%$ other high-tech & $28.1 * *$ & $37 *$ & $48.8 *$ & 24.4 & 18 & $25^{*}$ \\
\hline$\%$ medical device & 12.5 & 7.4 & $4.1 *$ & $15.6^{121}$ & 4.5 & 6.7 \\
\hline$\%$ bio-pharma & $15.6^{*}$ & $20.4 *$ & $16.3 *$ & 0 & 0 & 0 \\
\hline
\end{tabular}

${ }^{117}$ Comparing Product Company versus NPE patents, suits, and assertions.

118 Out of 28 total that cover medical devices, ten patents, which collectively account for 11 suits and 15 assertions (out of 35 and 102 total, respectively, involving medical devices), are also high-tech related; 5 of the 10, which account for 5 suits and 6 assertions, are software-related.

${ }^{119}$ Out of 11 total that cover medical devices, four patents, which collectively account for 7 suits and 24 assertions (out of 15 and 58 total, respectively, involving medical devices), are also high-tech related; 1 of the 4, which accounts for 3 suits and 6 assertions, is software related.

${ }^{120}$ Comparing patents, suits, and assertions resolved more than and less than three years before expiration.

121 Two medical device patents, which collectively account for three suits and ten assertions, are also high-tech related. 
Table 9: Litigation Outcomes

\begin{tabular}{|c|c|c|c|}
\hline & Product Co. & NPE & $p$-value \\
\hline \multicolumn{4}{|l|}{ Overall: } \\
\hline Adjudicated & $19.6 \%$ & 19.3 & \\
\hline Infringed & $48.4 \%^{122}$ & 25 & 0.091 \\
\hline Non-infringed & $29.7 \%$ & 56.3 & 0.046 \\
\hline Invalid & $29.7 \%^{123}$ & $25^{124}$ & \\
\hline Lit complete, > 3 yrs from exp: & \multicolumn{3}{|c|}{$* p$-value $<0.05 * * 0.1>p$-value $>0.05^{125}$} \\
\hline Adjudicated & $18.2 \%$ & 18.9 & \\
\hline Infringed & $43.4 \%$ & 28.6 & \\
\hline Non-infringed & $32.1 \%$ & 57.1 & \\
\hline Invalid & $28.3 \%$ & 28.6 & \\
\hline \multicolumn{4}{|l|}{ In lit, < 3 yrs from exp: } \\
\hline Adjudicated & $34.4 \% *$ & 20 & \\
\hline Infringed & $72.7 \% * *$ & 22.2 & \\
\hline Non-infringed & $18.2 \%$ & 55.6 & \\
\hline Invalid & $36.4 \%$ & 22.2 & \\
\hline
\end{tabular}

\section{IMPLICATIONS}

The results presented above demonstrate that NPEs play a more important role in the patent system than previously recognized, and a role that only becomes fully apparent when NPE litigation is examined in relation to the age of litigated patents. In short, while NPEs do not assert the majority of litigated patents or even file the majority of patent suits, they play an extraordinarily dominant role in patent litigation resolved or filed in the waning years of the patent term.

\section{A. NPEs are Mostly Not Technology Disseminators; Product Co. 's are Not Entirely Blameless}

What does this fact mean for our opinion of NPEs? For one, it serves as one more nail in the coffin of NPEs' claims that they play a "central role in helping commercial entities obtain the rights to use valuable technologies that produce new and beneficial products." 26 NPEs asserting patents filed by others roughly two decades ago cannot credibly claim that they are championing the rights of their accused infringers' contemporaneous

\footnotetext{
${ }^{122}$ One product company asserted patent was found both infringed and not infringed in different cases.

${ }^{123}$ Four product company asserted patents were adjudicated before being invalidated. Two were found infringed, and two were found not infringed.

${ }^{124}$ One NPE asserted patent was found both not infringed and invalid.

125 Comparing the outcomes of patent enforcement resolved more than and less than three years before expiration.

${ }^{126}$ John C. Paul, et al., Patent Trolls: A Stereotype Causes a Backlash Against Patents and Licensing, 41 LES NOUVELLES 224, 232 (2006).
} 
competitors. Similarly, with the notable exception of individual inventors, NPEs asserting their own patents are by no means rushing to the courthouse to vindicate their own rights soon after their patents issue. Instead, NPEs appear to be engaged in classic "troll-like" behavior: suing the better part of a well-established industry for infringement of an aging patent, generally one covering software or high-tech subject matter, and overwhelmingly losing when pushed to prove their infringement allegations. ${ }^{127}$

NPEs' role as vindicators of hard-fought patent rights becomes even less plausible taking into consideration the breakdown of NPE-asserted patents by technology and industry. Overall, almost $64 \%$ of NPE patents cover high-tech subject matter - about $40 \%$ are software related. Worse still, more than $80 \%$ of NPE-filed suits assert high-tech patents, and more than $65 \%$ have software-related claims. None cover pharmaceutical or biotech inventions, and less than $14 \%$ cover medical devices. ${ }^{128}$ Among NPE patents asserted in suits ongoing within three years of their expiration, almost $47 \%$ are software patents and more than $70 \%$ are high-tech related. And, on a per assertion basis, $86 \%$ of NPE patent enforcement in the final three years of protection is high-tech focused. In essence, where innovation is rapid and cheap, NPEs dominate, and where innovation is slow and expensive, NPEs are nowhere to be found.

Interestingly, a significant portion of product company litigation ongoing in the waning years of the patent term fares little better. Among product-company patents in litigation within three years of expiration, a large percentage (about 56\%) cover high-tech invention. On a per assertion basis, this rate jumps to over $70 \%$. Perhaps not surprisingly, upon closer examination, many of the suits responsible for this jump bear the hallmarks of troll litigation even though they were brought by a product-producing patentee. Several are suits filed by failing (but not yet failed) companies hoping to keep their doors open just a little while longer. Film and camera maker Kodak, for example, sued virtually every manufacturer of smart phones, seeking $\$ 1$ billion in damages for infringement of an old software patent covering image preview technology. ${ }^{129}$ Encyclopedia Britannica

\footnotetext{
${ }^{127}$ The breadth and age of NPE patents could alternatively suggest that these patents are far from stale and, instead, cover inventions so ahead of their time that it not until years later that commercial applications (and thus products) emerged. A growing body of scholarship, however, strongly suggests that "pioneer" inventions of this sort do not exist. See Mark A. Lemley, The Myth of the Sole Inventor, 110 MicH. L. REV. (forthcoming 2012); Brian J. Love, Interring the Pioneer Invention Doctrine, 90 N.C. L. ReV. (forthcoming 2012); Samson Vermont, Independent Invention as a Defense to Patent Infringement, 105 MicH. L. REV. 475 (2006).

${ }^{128}$ Many of these medical device patents, in turn, have a significant high-tech or software component. See supra note _.

${ }^{129}$ See Research in Motion, Ltd. v. Eastman Kodak Co., No. 08-CV-2075 (N.D. Tex.);
} 
launched a similar patent offensive against, curiously enough, the GPSmapping industry for infringement of a notoriously broad software patent. ${ }^{130}$ Other suits were filed by product companies that acquired patent rights purely for the purposes of litigation. Gemstar-TV Guide, ${ }^{131}$ for example, acquired the right to assert, among others, patents owned by former satellite-TV company SuperGuide in a long-running patent battle with the DVR industry and others. ${ }^{132}$ Several others suddenly asserted aging high-tech patents that had changed hands several times over a number of years, or asserted such patents against an entire industry. ${ }^{133}$ These suits, the likes of which do not occur earlier in the patent term, support one point

Eastman Kodak Co. v. Apple, Inc., No. 10-CV-6022 (W.D.N.Y.); RICH DuPREY, THE WORST STOCKS OF 2010: EASTMAN KodAK, THE Motley FoOL, JAN. 21, 2010, http://www.fool.com/investing/general/2010/01/21/the-worst-stocks-for-2010-eastmankodak.aspx (noting that Kodak "sees its future as being little more than a patent troll" because "[a]s its film business collapsed, Kodak was left with few options other than to turn to its patent portfolio to eke out a living"); JASON MICK, KODAK DEMANDS OVER \$1B USD FROM APPLE, RIM FOR ALLEGED INFRINGEMENT, DAILY TECH, MAR. 25, 2011, http://www.dailytech.com/Kodak+Demands+Over+1B+USD+From+Apple+RIM+for+All eged+Infringement/article21228.htm (noting also that in recent years Kodak "went on a patent binge, spending on patents and acquiring small startups" especially to "beef up its digital imaging IP"). Kodak recently put more than 1,000 patents up for sale in hopes of generating $\$ 2$ billion in revenues. See Robert Stammers, Is Kodak Worth \$3 Billion?, FORBES, Aug 2011, 30, available at http://www.forbes.com/sites/cfainstitute/2011/08/30/is-kodak-worth-3-billion/.

${ }^{130}$ See Encyclopaedia Britannica, Inc. v. Alpine Elec. of Am., Inc., No. 05-CV-359 (W.D. Tex.); Encyclopaedia Britannica, Inc. v. Magellan Navigation, Inc., No. 07-CV-787 (W.D. Tex.); Posting of Mike Masnick to TechDirt, It Appears that the Encyclopedia Britannica Entry on Shaking Down GPS Providers with a Bogus Patent Needs Updating, http://www.techdirt.com/articles/20100625/2351149966.shtml (June 28, 2010, 11:56).

${ }^{131}$ Gemstar merged with TV Guide, Inc. in July 2000, and was subsequently acquired by Macrovision (now Rovi Corp.) in May 2008.

${ }^{132}$ See SuperGuide Corp. v. DirecTV Enters., Inc., No. 00-CV-144 (W.D.N.C.); In re Certain Set-Top Boxes \& Components Thereof, No. 337-TA-454 (Int'l Trade Comm.); Richard RAYSMAN, ET AL., EMERging TeChNOLOGIES AND THE LAW, VOL. 2 §.05[5] (2003) (describing how Gemstar "expanded its portfolio of patents through various licensing arrangements" and began to enforce those rights aggressively in an effort to gain "a controlling position in the market for interactive programming guides," a market which matured to include technology far more advanced than what was envisioned in Gemstar's "aging patent portfolio").

${ }^{133}$ My sample included a number of high-tech patents originally assigned to AT\&T Bell Labs that changed hands after the company's spin-off to Lucent and eventually found their way into court in the mid to late 2000s. See U.S. Patent Nos. 5,298,047; 5,287,427; $5,243,229 ; 5,235,659$. Another high-tech patent, owned by Anvik Corp., was asserted in 12 suits against 35 defendants (essentially every flat-panel display/TV manufacturer) in the late 2000s. U.S. Patent No. 5,285,236; see also U.S. Patent No. 5,233,629 (software patent that changed hands in 2009 and was asserted for the first time that same year in three suits against six defendants). 
NPEs have made for years: product companies are just as capable of filing suspect patent suits as NPEs.

\section{B. Patent Term or Maintenance Fee Reform}

Together, the suspect quality of litigation brought by NPEs and product companies late in the patent term suggests that Congress might enhance innovation by shortening the patent term by three years, or even longer. In these final years of the patent term, product companies seem to have all but abandoned patents used to facilitate the introduction of new products years earlier. Many of those product companies left litigating aging patents appear to have the same motives and characteristics attributed to their much maligned troll adversaries - and presumably impose the same social costs. All things equal, ${ }^{134}$ a three-year term reduction would impact almost $44 \%$ of all NPE suits, ${ }^{135}$ while affecting roughly $12 \%$ of product company suits. ${ }^{136}$ On a per assertion basis, a three year term reduction could cut-short ${ }^{137}$ more than $32 \%$ of all NPE claims and eliminate almost $30 \%$ more, ${ }^{138}$ while cutting short fewer than $8 \%$ of product company assertions and eliminating just $5 \%$ more. $^{139}$

Though the majority of affected patents would merely expire during their final assertions (rather than before those are filed), there is good reason to believe the balance of power would still shift dramatically in these cases. Without live patents, patentees cannot seek permanent injunctions or ongoing royalties if they ultimately win their infringement claims. The possibility of both remedies gives patentees leverage to hold-up accused infringers for outsized settlements. ${ }^{140}$

${ }^{134}$ Of course, all things might not remain equal following patent term reform. See infra Part III.C.

135 Of 253 total NPE suits, 45 were filed in the last three years of the patent-in-suit's term and another 66 were resolved within the same time period though filed a bit earlier.

${ }^{136}$ Of 447 total product company suits, 26 were filed in the last three years of the patent-in-suit's term and another 28 were resolved within the same time period though filed a bit earlier.

137 By "cut-short," I mean that the patent-in-suit would expire during litigation. Patentees could continue to litigate for past infringement, but would be precluded from receiving an injunction or ongoing royalty after winning summary judgment or at trial because the alleged infringer's future activities would no longer potentially infringe.

${ }^{138}$ Of 978 total NPE claims, 290 were brought within three years of the patent-in-suit's expiration and another 278 were resolved during the same period but filed earlier.

139 Of 949 total product company claims, 48 were brought within three years of the patent-in-suit's expiration and another 75 were resolved during the same period but filed earlier.

${ }^{140}$ See Mark A. Lemley \& Carl Shapiro, Patent Holdup and Royalty Stacking, 85 TEX. L. REV. 1991 (2007); Mark A. Lemley, The Ongoing Confusion Over Ongoing Royalties, 
Furthermore, there is good reason to believe that product companies could easily be, and as a practical matter would be, insulated from a term reduction to a degree greater than the statistics above suggest. For one, any legislation reforming the patent term could exclude practicing patentees in the biotech, pharmaceutical, and medical device industries, which collectively assert about $28 \%$ of product-company patents litigated in the final three years of the patent term. Unlike their high-tech counterparts, these patents cover well defined and well known products approved by the FDA, and are frequently litigated at the very end of the patent term against generic manufacturers seeking a leg up in the production of low-cost alternatives to successful name brand drugs, diagnostics, and devices. Would a term reduction harm incentives to produce more of these lifesaving inventions? Perhaps not. Pharmaceutical companies are exceedingly skillful at extending their market power over drugs by filing newer patents covering related subject matter - a process known as "evergreening." "141 In fact, for this very reason, a term reduction would impact product companies far less than one might anticipate because, unlike NPEs, a product company can always file new patents covering improved, next-generation versions of its products. That is, while a product company with an expired patent likely has recourse to additional similar patents, an NPE with an expired patent is out of luck and must purchase a replacement.

In any event, it would be logistically simple to exclude medical, biotech, and pharmaceutical patents from any legislation curtailing late term patent rights because the PTO already has experience singling out such inventions for special treatment. Current law already permits term extensions for patents covering products that require FDA approval. ${ }^{142}$ These existing

at *9-10 (working paper 2011) (noting, for example, that some courts have granted trebled ongoing royalties on the theory that adjudicated infringers who continue to sell the infringing products are "willful" infringers). Post eBay, Inc. v. MercExchange, L.L.C., 547 U.S. 388 (2006), the possibility that a successful NPE will receive injunctive relief is diminished, but certainly non-zero. See Lily Lim \& Sarah E. Craven, Injunctions Enjoined; Remedies Reconstructed, 25 SANTA ClARA COMP. \& HiGH TECH. L.J. 787, 798 (2009) (noting that post-eBay "a patentee who directly competes in the marketplace with the infringing party gets an injunction $79.6 \%$ of the time, while an NPE's chance of an injunction falls precipitously to $33.3 \% "$ ").

141 Rebecca S. Eisenberg, The Role of the FDA in Innovation Policy, $13 \mathrm{MICH}$. TELECOMM. TECH. L. REV. 345, 354 (2007) ("Examples include patents on 'metabolites' (i.e., the products into which drugs are transformed in a patient's body); patents on intermediate products used in producing drugs; patents on new uses for drugs; and patents on new formulations or preparations."); see also Tamsen Valoir, Six Methods of Preserving Market Exclusivity, INTELL. PROP. \& TECH. L.J., Nov. 2006, at 12, 14.

14235 U.S.C. $\$ 156$ (enacted as part of the Hatch-Waxman Act). Related sections of the Patent Act provide product-specific term increases. See id. at $\S \S 155,155 \mathrm{~A}$ (providing additional protection to Aspartame and Forane). Thus, while it may be exceedingly 
provisions could be reformed to lower the bar for term extensions or, quite simply, to exclude patents owned by the makers of FDA-approved medicines, diagnostics, or devices from any term reduction reforms. ${ }^{143}$

Excluding from the tally cases and assertions brought by pharmaceutical, biotech, and medical device firms, a modified three-year term reduction would impact less than $8 \%$ of all product-company suits and roughly $10 \%$ of assertions. ${ }^{144}$ Taking product-company "trolling" into account would reduce this percentage even further. Additionally excluding those suits and assertions brought by the troll-like product companies mentioned above, a three-year reduction in the patent term would disrupt less than $4 \%$ of "legitimate" product company patent suits and less than $5 \%$ of all assertions. ${ }^{145}$

\section{Limitations}

One thing this study cannot predict, however, is how patentees would adjust their litigation timing in response to a term reduction. Though, as discussed above, patents often do not reach NPEs for years, a substantial component of NPE litigation delay is simply that: delay. On average NPEs wait about 3.5 years to file suit after obtaining a patent. In theory, then, most NPE enforcement could have been initiated years earlier. Requiring NPEs to race to the courthouse would no doubt have significant benefits. It would, for example, force some NPEs to litigate before the technology they accuse is irrevocably incorporated in technology standards or costly fixed investments, and therefore reduce the hold-up power many NPEs now enjoy. ${ }^{146}$ Nonetheless, the results reported above must be discounted to some extent by uncertainty about NPEs' ability to sue earlier.

Further, while I have used the terms "enforcement" and "litigation" above interchangeably, the results of this study are only as strong as the degree to which the temporal bounds of litigation match those of all patent enforcement. Because patent licenses negotiated outside the court system are almost always kept confidential, it is virtually impossible to measure the

difficult, if not impossible, to draw bright lines between many other industries, it appears to be relatively simple to separate this cohort of patents. None of the pharmaceutical, biotech, or medical device patents in my sample received a term extension. A list of extended patents is available at http://www.uspto.gov/patents/resources/terms/156.jsp.

${ }^{143}$ Requiring the commercialization of a product would exclude NPE-asserted medical device patents (more than $13 \%$ of all NPE patents) from the benefit of any such reform.

${ }^{144}$ Collectively, these patentees filed 15 suits, accounting for 25 assertions, resolved within three years of the patent-in-suit's expiration.

${ }^{145}$ Collectively, these patentees filed 20 suits, accounting for 54 assertions, resolved within three years of the patent-in-suit's expiration.

${ }^{146}$ See Lemley \& Shapiro, supra note _. 
total level of patent enforcement that product companies undertake after ceasing litigation, that NPEs undertake before filing suit, and that all patentees undertake with patents that are never asserted in court.

While the amount of each is certainly non-zero, there is also good reason to believe that this source of uncertainty is not fatal to studies of this kind. First, while some NPEs do attempt to license their patents without litigation, $^{147}$ they face at least one very strong incentive not to: the importance of forum selection. A threatened product company can, and generally will if litigation seems imminent, file a declaratory judgment action in a favorable jurisdiction in an attempt to prevent the impending suit from proceeding in a patentee-friendly district. ${ }^{148}$ What it almost certainly won't do is closely review unsolicited license offers from small NPEs. ${ }^{149}$ Accordingly, it seems reasonable to assume that the most sophisticated NPEs, especially those who are repeat players, adopt a litigate-first strategy, and that sophisticated product companies do, too, when confronted with serious NPE infringement claims.

Unlike NPEs, however, product companies do have a history of dealing with one another outside the confines of litigation. One reason is that patent litigation is notoriously costly, but especially so for accused infringers. This cost-asymmetry makes litigation attractive for NPEs who cannot be countersued for infringement, and unattractive for product companies who generally will be and, furthermore, will have to deal with their opponent repeatedly in the future. ${ }^{150}$ In addition to litigation expenses, competitors

${ }^{147}$ See Michael J. Meurer, Controlling Opportunistic and Anti-Competitive Intellectual Property Litigation, 44 B.C. L. REV. 509, 517 (2003) (noting that E-Data, a company that "owns a patent which arguably covers financial transactions on the Internet," reportedly sent demand letters to 75,000 alleged infringers before suing forty-one companies for patent infringement).

148 See Kimberly A. Moore, Forum Shopping in Patent Cases: Does Geographic Choice Affect Innovation?, 79 N.C. L. REV. 889, 920-21 (2001) ("In cases in which the defendant was able to choose the forum (as with declaratory judgment actions) rather than the patent holder (as in infringement suits), there was a significant difference in outcome: . ... When the patent holder selects the forum, the patent holder wins $58 \%$ of the claims. When the accused infringer brings a declaratory judgment action and thereby chooses the forum, the patent holder win rate drops to $44 \%$."). But $c f$. Chester S. Chuang, Offensive Venue: The Curious Use of Declaratory Judgment to Forum Shop in Patent Litigation, 80 GEO. WASH. L. REV. (forthcoming 2012) (finding that declaratory judgment actions are a surprisingly ineffective means to avoid pro-patentee forums).

149 See Mark A. Lemley, Ignoring Patents, 2008 MicH. ST. L. REV. 19, 21-22 (noting that companies generally ignore patents in all stages of product development: when conducting research and design, when filing their own patents, when launching new products, and even after receiving initial cease-and-desist letters from patent owners).

${ }^{150}$ See Crane, supra note _, at 286; Chistopher A. Cotropia, The Individual Inventor Motif in the Age of the Patent Troll, 12 Yale J. L. \& Tech. 52, 55 (2009) ("If a defendant is sued by one of these patent trolls, the alleged infringers do not have the usual retaliatory 
face other strong incentives not to challenge each other's patents; for example, the fact that they bear the cost of the challenge but share the benefit of invalidation with the rest of the industry and future competitors. $^{151}$ All of these factors suggest that, between product companies, patent litigation is generally a last resort used against especially recalcitrant competitors, not the first resort it is for NPEs. Finally, at least among product companies that actively license their patent portfolios, it is standard practice to license relatively large pools of patents, rather than a select few individuals. ${ }^{152}$ Removing the oldest patents from a large pool seems unlikely to substantially reduce its value to a competitor looking to clear a path to commercialize a new, cutting edge product, and, accordingly, it would be disingenuous to attribute much, if any, of the value of such a license to the most aged patents in the pool. ${ }^{153}$

mechanism - the ability to assert their own patents in return-because the patent troll does not sell any products or offer any services which could infringe.").

151 Joseph Farrell \& Robert P. Merges, Incentives to Challenge and Defend Patents: Why Litigation Won't Reliably Fix Patent Office Errors and Why Administrative Patent Review Might Help, 19 BERKELEY TECH. L.J. 943, 958 (2004) ("[A] challenger bears the cost of litigation but its rivals and downstream buyers will capture almost all the benefits of successful challenge ....”).

152 See Gideon Parchomovsky \& R. Polk Wagner, Patent Portfolios, 154 U. PA. L. REV. 1, 8-9 (2005) ("While large firms provide perhaps the most compelling example of patent portfolios in practice ... we also find real world case studies of patenting behavior consistent with our theory among startups and acquisition-centric firms. Indeed, the rise of patent portfolios in the business community has become so significant that portfolios have become the credo of firm value in the modern innovation environment.").

${ }^{153}$ See Parchomovsky \& Wagner, supra, at 1 ("We find that for patents, the whole is greater than the sum of its parts: the true value of patents lies not in their individual worth, but in their aggregation into a collection of related patents--a patent portfolio.").

One additional limitation is also worth mentioning. There is a perception among many in the patent community that the NPE business model is largely a recent phenomenon popularized after the burst of the dot-com bubble. See, e.g., John A Marlott, NPEs and Pre-Litigation Considerations, 1020 PLI/Pat 453, 457 (2010). If true, my findings on lateterm NPE litigation might be inflated by the fact that few NPEs were around prior to 2000 to file suit on patents issued in earlier years. Recent scholarship casts serious doubt the accuracy of this perception, however. Michael Risch found that, contrary to conventional wisdom, large-scale NPE operations date back to at least the mid-1980s, were very active in the 1990s, and in some instances markedly decreased their activity in the 2000s. Risch, supra note _, at 15-16 (reporting that, of the ten most litigious NPEs since 2003, two filed their first suit in 1986, nine began operating in the 1990s, and three actually ceased filing suits altogether in the 2000s). Risch does report a weak correlation between NPE patent issue date and shelf time prior to suit, but notes that this correlation is at least partly explained by selection effects. Id. at 27-28 (finding among patents asserted by the ten most litigious NPEs a correlation of 0.23 between issue date and time to first suit, but acknowledging that his study includes only those recently issued patents that were litigated prior to 2010). But cf. Chien, Of Trolls, supra note _ at 1604 (finding that NPEs' share of high-tech patent litigation increased overall between 2000 and 2008, despite the fact that it 


\section{Maintenance Fee Reform}

Is the potential disruption of between 4 and $5 \%$ of product company assertions (44 claims in this study) worth trading for the potential elimination of $32 \%$ of NPE claims and the dilution of almost $30 \%$ more (568 total claims in this study)? Perhaps not, given the limitations discussed above. A less drastic reform, and one that has the added benefit of not violating the U.S.'s obligations under GATT/TRIPS, would be to increase the frequency and magnitude of maintenance fee payments in the latter half of the patent term. Today, patent owners are free from payment obligations less than twelve years after issue, not long after the tide of patent litigation shifts in NPEs' favor. ${ }^{154}$

Congress could require additional annual fees for years nine through eleven and thirteen through sixteen (or longer) and, moreover, could substantially increase the fee required each year. ${ }^{155}$ Such a reform might very well result in the premature expiration of many patents that would otherwise end up in the hands of patent acquisition firms, while at the same time permitting product companies profiting from lucrative confidential licensing agreements to extend their patents up to twenty years from filing. Moreover, the rates at which patentees renew their patent rights late in the term would shed additional light on the private value of aging patents that

decreased between 2002 and 2005, but making no findings with respect to the ages of asserted patents).

${ }^{154}$ Under current law, maintenance fees are due at 3.5 years $(\$ 980), 7.5$ years $(\$ 2480)$, and 11.5 years $(\$ 4110)$. 37 C.F.R. $§ 1.20(\mathrm{e})-(\mathrm{g})$. Patentees that qualify as "small entities" pay only half this amount. Id.

155 See Kimberly A. Moore, Worthless Patents, 20 BERKELEY TECH. L.J. 1521, 155152 (2005) (recommending annual maintenance fee payments); Francesca Cornelli \& Mark Schankerman, Patent Renewals and R\&D Incentives, 30 RAND J. ECON. 197, 197 (1999) (finding that a sharper rise in patent renewal fees would increase welfare). U.S. patent renewal requirements are far less onerous than those in place in many other countries. Annual maintenance fees are common in other countries. See, e.g., EuROPEAN PATENT CONVENTION, Pt. III, Chp. 1, Art. 86, available at http://www.epo.org/law-practice/legaltexts/html/epc/2010/e/ar86.html ("Renewal fees for the European patent application [recognized in 38 member states] . . . shall be due in respect of the third year and each subsequent year, calculated from the date of filing of the application."); Renewing Your Patent, U.K. I.P.O., http://www.ipo.gov.uk/types/patent/p-manage/p-renew.htm (explaining that in the UK patents must be "renew[ed] . . . on the 4th anniversary of the filing date and every year after that . . . . up to 20 years"); CANADIAN I.P.O., MANUAL OF PATENT OFFICE PRACTICE § 24.02 .01 (Sept. 2004), available at http://www.ic.gc.ca/eic/site/cipointernetinternetopic.nsf/vwapj/chapitre24-chapter24-eng.pdf/\$file/chapitre24-chapter24-eng.pdf ("In order to maintain a patent application in effect, an applicant must pay maintenance fees for each one-year period from the second anniversary of the filing date of the application."). 
could help tailor a future term reduction years down the road. ${ }^{156}$

\section{CONCLUSION}

Whatever the precise mechanism employed, the results presented in this Article suggest that patent rights should diminish, at least marginally if not completely so, earlier than they do under current law. In a world in which at least some products are out of date by the time they hit store shelves, the last few years of a two-decade-long patent term seem unlikely to incentivize greater innovation. To the contrary, it appears that the waning years of patent protection primarily serve to benefit a growing number of litigationoriented patentees who do little more with their aging patent rights than impose steep legal costs on those selling successful products. Perhaps through future research that dispels concerns raised by the limitations discussed above, we will soon gain a deeper understanding of the practical costs and benefits of the final years of the patent term that will spur legislative action to trim the nation's ever-increasing thicket of aging patents.

156 See Chien, Predicting Patent Litigation, supra note _, at *25 ("The decision to maintain a patent signals its private value to the patent owner."').

Other possible reforms exist that might mitigate the costs of late-term patent enforcement. For example, the U.S. could implement a rule, loosely related to "working requirements" in effect in many countries around the world, that patent rights expire unless they have been the subject of at least one bona fide license or good faith patent suit within a certain number of years following issue. See generally Janice M. Mueller, The Tiger Awakens: The Tumultuous Transformation of India's Patent System and the Rise of Indian Pharmaceutical Innovation, 68 U. PITT. L. REV. 491, 593-97 (2007). (discussing the history of working requirements). Alternatively, Congress or the courts could institute a new defense akin to laches that denies relief to patentees who fail to quickly seek out potential infringers and initiate licensing negotiations before filing suit. See Tun-Jen Chiang, The Reciprocity of Search, at *30-31 (working paper) (arguing that 35 U.S.C. $\S$ 287 should be reformed to implement a "contributory search defense"). 